\begin{tabular}{l|c|c}
\hline ISSN: 0001-5113 & ACTA ADRIAT., & ORIGINAL SCIENTIFIC PAPER \\
AADRAY & $62(1): 21-44,2021$ & \\
\hline
\end{tabular}

\title{
Comparison of benthic diatom community structures on natural and artificial substrates in marine lake (Adriatic Sea)
}

\author{
Ana CAR ${ }^{1}$, Dubravka HAFNER ${ }^{1,}$ Iris DUPČIĆ RADIĆ ${ }^{1 *}$, Aydin KALELI $^{2}$, \\ Stijepo LJUBIMIR ${ }^{1}$ and Cüneyt NADIR SOLAK ${ }^{3}$ \\ ${ }^{1}$ University of Dubrovnik, Institute for Marine and Coastal Research, 20000 Dubrovnik, Croatia \\ ${ }^{2}$ Department of Marine and Freshwater Resources Management, Faculty of Aquatic Sciences, \\ Istanbul University, Istanbul, Turkey \\ ${ }^{3}$ Department of Biology, Faculty of Science and Arts, Kütahya Dumplupinar University, \\ Kütahya, Turkey
}

Corresponding author, e-mail: iris@unidu.hr

In this study, the diatoms of three alternative habitats (epilithon, epiphyton and artificial substrate) were compared to understand the differences in composition on artificial and natural substrates. For this purpose, the samples were collected weekly between 11th August and 2nd September 2016 at a sampling site in a shallow marine lake, Mrtvo More (Dead Sea) on Lokrum Island near Dubrovnik (South Adriatic, Croatia).

In addition to detailed light microscopic analysis, ultrastructural analysis of benthic diatoms from Lake Mrtvo More was performed for the first time using scanning electron microscopy (SEM). A total of 97 taxa were identified in 12 samples. Cocconeis scutellum Ehrenberg and Halamphora coffeiformis (C.Agardh) Levkov were the most frequent taxa in the samples. Shannon-Wiener diversity index ( $H^{\prime}$ ) values varied from 1.78 (in September on Padina sp.) to 4.52 (in August on glass). According to non-metric multidimensional scaling ordination, there were two groups: epilithon and artificial glass substrate as Group1 and macroalgae as Group2.

The results of the analysis showed that the diatom communities developing on artificial substrates accurately corresponed to the diatom community of a rock substrate and thus can be used as a representative alternative tool for studies of epilithic diatoms in further experiments.

Key words: Bacillariophyta; shallow marine lake; species identification; biodiversity; NE Mediterranean 


\section{INTRODUCTION}

The marine lake Mrtvo More is located on Lokrum Island near Dubrovnik. Since 1948, Lokrum Island has been a special reserve of forest vegetation and today the island (72 ha) and the sea-belt are also a Natura 2000 site (CRNČEVIĆ et al., 2017). As a geomorphological phenomenon, the Mrtvo More with its pit hole and the channel connecting the marine lake to the open sea is a Natura 2000 habitat of the type 'Submerged or partially submerged sea cave'.

Benthic diatoms are unicellular or colonial organisms that are free-living or attached to the substrate by gelatinous extrusion and play an important role in primary production in marine ecosystems (FALKOWSKI et al., 2004). They are used as water quality indicators as well as in paleoecological reconstructions due to their ecophysiological features (CIBIC \& BLASUTTO, 2011; STEVENSON \& PAN, 1999). Knowledge of the structure of the benthic diatom community and the ecology of individual taxa is a unique source of information in the study of the dynamics of marine microphytobenthos.

Some of the potential advantages of using artificial substrates in diatom studies include reduced effort and cost of sampling and processing, less habitat disruption, and substantially improved sampling precision (LAMBERTI \& RESH, 1985; LANE et al., 2003). The greatest benefit of using an artificial substrate over sampling natural habitats is the consequent standardization between replicates. Additionally, the use of artificial substrates for monitoring purposes does not compromise the algal settlements and artificial substrates can be used globally as they are not limited by the natural lifecycle and distribution range of the macroalgae (CARREIRAFLORES et al., 2020).

Although artificial substrates have been used in diatom studies for almost 100 years (NAUMANN, 1915; cited in TUCHMAN \& STEVENSON 1980; HOAGLAND et al., 1986; BARBIERO, 2000), there are still concern whether diatom communities developing on artificial substrates accurately correspond to communities developing on natural substrates (LANE et al., 2003).
Ideally artificial substrates should support a community composition and abundance that is representative of natural substrates at the same site (TUCHMAN \& STEVENSON, 1980; LAMBERTI \& RESH, 1985; LANE et al., 2003). It may be, for example, that diatom communities developing on artificial substrates more closely represent the diatom community of a particular natural substratum (LANE et al., 2003). Hence the need exists for further comparative research examining diatom community structure on artificial and various natural substrates.

In the Adriatic Sea, benthic diatoms from natural sediment samples and artificial substrates have been reported from various areas, including: the Gulf of Trieste (BARTOLE et al., 1991-94; SDRIGOTTI et al., 1999; MUNDA, 2005), the Venice Lagoon (TOLOMIO \& ANDREOLI, 1989; TOLOMIO et al., 1999; FACCA et al., 2002; TOLOMIO et al., 2002; FACCA \& SFRISO, 2007), the Northwestern Adriatic coast (TOTTI 2003; TOTTI et al., 2007; FRANZO et al., 2015, and references therein), and the Eastern Adriatic Sea coast (BURIĆ et al., 2004; MIHO \& WITKOWSKI, 2005; CAPUT et al., 2008; LEVKOV et al., 2010; CAR et al., 2012, 2019a,b, 2020; NENADOVIĆ et al., 2015; MEJDANDŽIĆ et al., 2015; HAFNER et al., 2018a,b; KANJER et al., 2019). Nevertheless, knowledge about the composition and spatial distribution of marine benthic diatoms around the coast of the South Adriatic remains limited.

The objective of this work was to contribute to the knowledge of microphytobenthos in the Adriatic Sea, by studying benthic diatom communities on an immersed artificial substrate and natural substrates with various physicochemical properties in the shallow marine lake Mrtvo More (Dead Sea) on Lokrum Island near Dubrovnik (South Adriatic, Croatia) in a period of intense anthropogenic influence due to tourist activities.

The main goal of this work was to investigate the potential for using artificial substrates for benthic diatom assemblage monitoring as an alternative to natural epiphyton and epilithon samples. Two hypotheses were proposed and tested: (1) that natural rocks and glass artificial substrates had similar diatom community struc- 
ture; and (2) macroalgae were sheltering different assemblages of benthic diatoms.

\section{MATERIAL AND METHODS}

\section{Study area}

The study was carried out at one station $\left(42^{\circ} 37^{\prime} 21^{\prime \prime} \mathrm{N}\right.$; $\left.18^{\circ} 7^{\prime} 14^{\prime \prime} \mathrm{E}\right)$ in the roughly circular-shaped marine lake Mrtvo More (Croatian: 'Dead Sea') situated in the southern part of the island of Lokrum near Dubrovnik (South Adriatic), Croatia (Fig. 1).

The island of Lokrum has a typical Mediterranean climate. The average annual air temperature of the Dubrovnik area is $16{ }^{\circ} \mathrm{C}$. The average temperature of the warmest months (July and August) is about $25^{\circ} \mathrm{C}$ and of the coldest (January and February) about $9{ }^{\circ} \mathrm{C}$. The rainiest and cloudiest month is November, and the driest and clearest is July. The average annual precipitation on Lokrum is $1360 \mathrm{~mm}$, while during 2016 a yearly rainfall of $1054 \mathrm{~mm}$ was recorded (meteorological data for the Dubrovnik area for 1961-2017, Croatian Meteorological and Hydrological Service; Fig. S1). Lokrum is directly exposed to sea currents from the south and the Strait of Otranto, which influences the distribu- tion of benthic organms and plankton (BATISTIĆ et al., 2014; GARIĆ \& BATISTIĆ, 2016).

\section{Sampling strategy and analyses}

\section{Physical-chemical parameters}

Water samples for analysis of physicochemical variables were taken weekly (Table 1) from $11^{\text {th }}$ August to $2^{\text {nd }}$ September 2016, at the same place where diatom sampling was carried out, i.e. near the bottom ( $1 \mathrm{~m}$ depth) at the investigated station located in the southern part of the Island of Lokrum (Fig. 1). All the samples were taken at the same time of the day (from 10 till $11 \mathrm{am})$. Temperature (T) and salinity (S) were measured using a WTW Multiline P4 multiparametric sounding lineprobe. Seawater samples were taken with a 5 L Niskin bottles and kept cold until analysis. Analyses of measured nutrients [nitrate $\left(\mathrm{NO}_{3}{ }^{-}\right)$, nitrite $\left(\mathrm{NO}_{2}{ }^{-}\right)$, ammonium $\left(\mathrm{NH}_{4}^{+}\right)$, total inorganic nitrogen $(\mathrm{TIN}=$ $\left.\mathrm{NO}_{3}{ }^{-}+\mathrm{NO}_{2}^{-}+\mathrm{NH}_{4}^{+}\right)$, orthophosphate $\left(\mathrm{PO}_{4}{ }^{3-}\right)$ and orthosilicate $\left.\left(\mathrm{SiO}_{4}{ }^{4-}\right)\right]$ and chlorophyll $a$ (Chl a) were performed following the standard procedures (APHA, 2005). Samples for $\mathrm{NO}_{3}^{-}$, $\mathrm{NO}_{2}{ }^{-}, \mathrm{PO}_{4}{ }^{3-}$, and $\mathrm{SiO}_{4}{ }^{4-}$ were frozen $\left(-22{ }^{\circ} \mathrm{C}\right)$ and analysed in laboratory according to Strickland

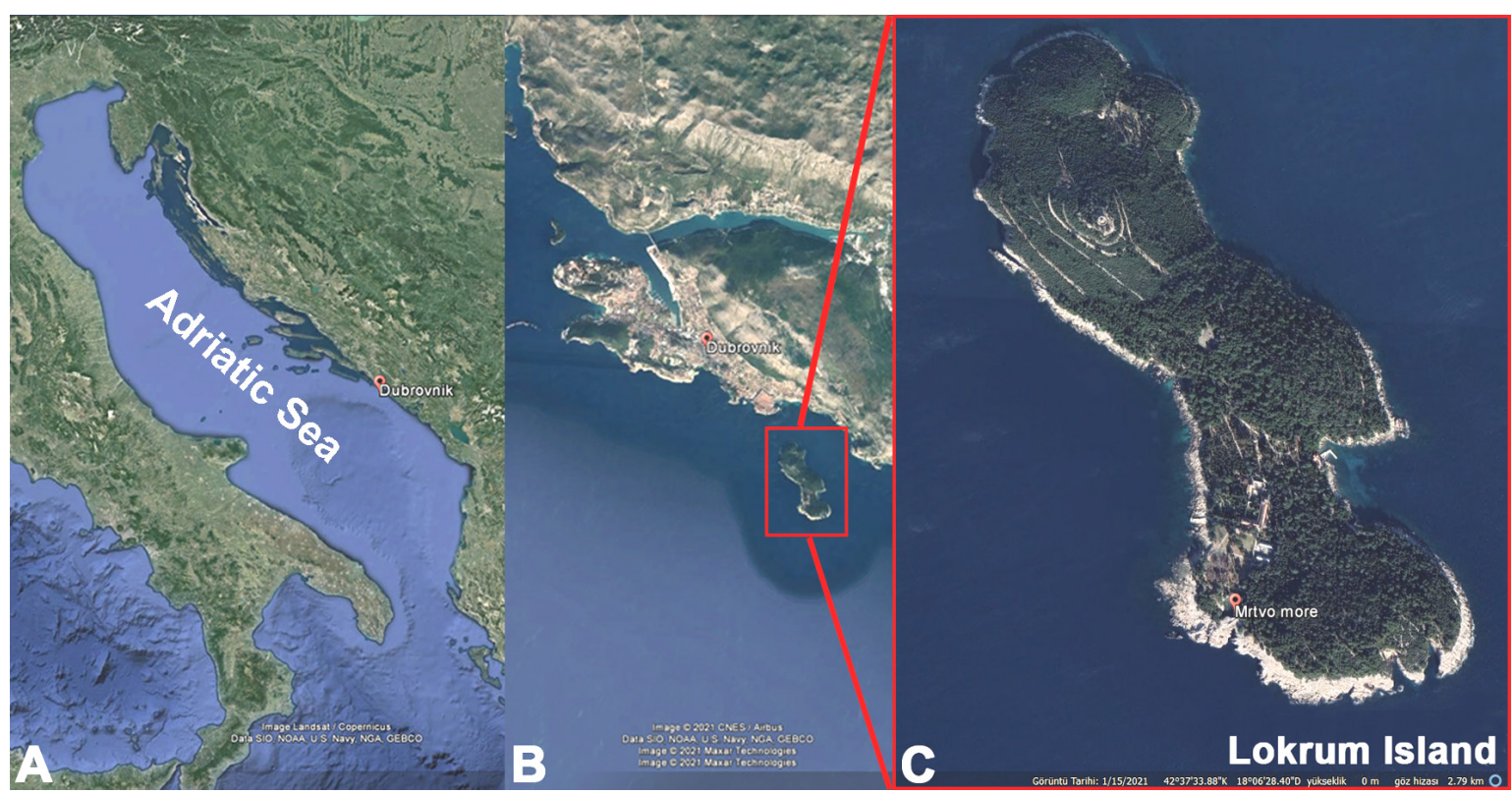

Fig. 1. Map of the study area. A) Location of sampling site in Adriatic Sea (•); B) Close up map of Dubrovnik area; C) position of Mrtvo More on southern side of Island of Lokrum (Google Earth, 6 June 2021) 
and Parsons (1972). Subsamples (50 mL) for $\mathrm{NH}_{4}{ }^{+}$were fixed immediately after collection with $2 \mathrm{~mL}$ of $1 \mathrm{molL}^{-1}$ phenol/EtOH, kept at 4 ${ }^{\circ} \mathrm{C}$ and later analysed according to IVANČIĆ \& DEGOBBIS (1984). Chl $a$ was determined from 1 L sub-samples filtered through Whatman GF/F glass-fiber filters and stored at $-20^{\circ} \mathrm{C}$ for a period of less than a month. Filtered samples were homogenized and extracted in $90 \%$ acetone for 24 hours at room temperature (HOLM-HANSEN $e t$ al., 1965). Chl $a$ was determined fluorometrically using a Turner TD-700 Laboratory Fluorometer (Sunnyvale, CA) calibrated with pure $\mathrm{Chl} a$ (Sigma).

Dissolved oxygen was determined by the Winkler method and oxygen saturation $\left(\mathrm{O}_{2} /\right.$ $\mathrm{O}_{2}{ }^{\prime}$ ) was calculated from the $100 \%$ solubility of oxygen $\left(\mathrm{O}_{2}\right)$ in seawater as a function of temperature and salinity (WEISS, 1970; UNESCO, 1973). Trophic status (TRIX index; $\left[\log _{10}(\mathrm{Chl}\right.$ $a \times \mathrm{D} \% \mathrm{O} \times \mathrm{DIN} \times \mathrm{TP})+\mathrm{k}] / \mathrm{m}$ ) was calculated according to factors which represent a variable reflected in the trophic state: $\mathrm{Chl} a=$ chlorophyll $a$ concentration $\left(\mu \mathrm{gL}^{-1}\right), \mathrm{D} \% \mathrm{O}=$ dissolved oxygen (absolute deviation from $100 \%$ oxygen saturation), dissolved inorganic nitrogen DIN and $\mathrm{TP}=$ total phosphorus $\left(\mu \mathrm{gL}^{-1}\right)$ (VOLLENWEIDER et al., 1998; GIOVANARDI \& VOLLENWEIDER, 2004; KARYDIS, 2009; PRIMPAS \& KARYDIS, 2011). The parameters $\mathrm{k}=1.5$ and $\mathrm{m}=1.2$, are scale coefficients, introduced to fix the lower limit value of the Index and the extension of the related Trophic Scale, from 0 to 10 TRIX units $(0-4$ oligotrophic, 4-5 mesotrophic, 5-6 eutrophic, 6-10 extremely eutrophic).

\section{Experimental setup and diatom analysis}

In order to test two proposed hypotheses, diatom samples were taken from the rocks, from the autochthonous brown alga Padina sp. and from standard glass microscope slides measuring about $75 \mathrm{~mm} \times 25 \mathrm{~mm} \times 1 \mathrm{~mm}$ used as a substrate for biofilm formation from the same locality to compare the diatom community on the artificial substrate (glass) with diatom communities from natural substrates. As an artificial substrate, microscope glass slides were fixed on the upper side of a plexiglass sheet. On 19 April 2016, the plexiglass sheet was submerged horizontally with four diving weights at a depth of approximately $1 \mathrm{~m}$ (i.e. on the bottom of Lake Mrtvo More) about $2 \mathrm{~m}$ offshore. Every week the plexiglass sheet was hauled up and another microscopic slide for diatom analysis was taken out and gently plunged into filtered seawater (Millipore, acetate cellulose $0.22 \mu \mathrm{m}$ ). For this survey, samples were collected at weekly intervals from the $11^{\text {th }}$ of August to $2^{\text {nd }}$ of September 2016.

For a quantitative biofilm assay a microscopic glass surface of $1 \mathrm{~cm}^{2}$ was scraped using a razor blade, and the microalgae were collected in Falcon tubes. Samples were preserved by adding a known amount $(3 \mathrm{~mL})$ of solution $(3 \%)$ of formaldehyde-filtered seawater. Quantitative analysis of homogenized samples was determined with an inverted microscope (Olympus IX 71) equipped with phase contrast. Results are expressed as number of cells per $\mathrm{cm}^{2}$.

The natural epilithic diatom communities were obtained by scraping off the randomly collected submerged rocks of $5-10 \mathrm{~cm}^{2}$ on which the diatom biofilm was visible. The upper parts of the rocks were rubbed with a toothbrush in a plastic bag of $1 \mathrm{~L}$ in which $200 \mathrm{~mL}$ of sterile freshly filtered seawater was added and the mixture decanted into $250 \mathrm{~mL}$ polyethylene bottles (WINTER \& DUTHIE, 2000). All samples were preserved with $4 \%$ formaldehyde. Over a period of one month 12 diatom samples were collected: 4 diatom samples from artificial substrates together with 4 diatom samples from Padina sp. and 4 diatom samples from the rocks. There were no replicate samples for diatom analyses.

After a quantitative biofilm assay, the glass slides were treated with $10 \%$ hydrochloric acid $(\mathrm{HCl})$ to remove carbonates and cleaned of organic material by boiling with $30 \% \quad \mathrm{H}_{2} \mathrm{O}_{2}$. They were then rinsed with deionized water, pipetted onto ethanol-cleaned cover-slips and left to air dry before mounting in Naphrax ${ }^{\circledR}$. Detailed light microscopy (LM) analysis was performed on permanent slides of processed material (hydrogen peroxide treated) with a Nikon E600 microscope at a magnification of 
$1000 \mathrm{x}$. The abundances of the species were expressed as percentages of the total number of frustules counted (relative abundances in \%). In total, 400 valves per each sample were counted. Permanent slides were deposited in the diatom collection of the Institute for Marine and Coastal Research, University of Dubrovnik, Dubrovnik, Croatia [no. AC-MM-517-528].

For scanning electron microscopy (SEM) a drop of the cleaned sample was air-dried on aluminium stubs and coated with gold using Emitech Quorum K550X. SEM observations were made at the Eskisehir Osmangazi Technical University (Turkey) using a Zeiss ULTRA Plus.

Identifications were made following PERAGALLO \& PERAGALLO (1897-1908), HENDEY (1964), RICARD (1974, 1975, 1977), POULIN et al. (1984, 1990), BÉRARD-THERRIAULT et al. (1986, 1987), HARTLEY (1986), SNOEIJS (1993, 1999), SNOEIJS \& POTAPOVA (1995), SNOEIJS \& KASPEROVICIENÉ (1996), SNOEIJS \& BALASHLOVA (1998), HARTLEY et al. (1996), WITKOWSKI et al. (2000) and KOCIOLEK et al. (2020). Nomenclature follows AlgaeBase (GUIRY \& GUIRY, 2020).

\section{Statistical analysis}

The data were analysed using the Primer v. 6 software (CLARKE \& GORLEY, 2006) and Statistica 7.0 (StatSoft, Inc. 2004).

The diatom community diversity and structure were investigated for each diatom sample. The Shannon-Wiener Biodiversity Index, the Margalef index (KWANDRANS, 2007) and the Pielou's evenness (PIELOU, 1966) were computed.

Raw diatom counts were expressed as relative abundance and transformed by square root to normalize the data. CLUSTER (using the group average mode and the SIMPROF test for significance) and non-metric multidimensional scaling (nMDS) analyses based on the Bray-Curtis dissimilarity matrix (LEGENDRE \& LEGENDRE, 1983; CLARKE \& GORLEY, 2006) of the relative abundance data of 97 taxa over 12 samples on square-root transformed density data, were used to define the benthic diatom abundance with respect to sampling dates. The significant dif- ferences among samples were determined using SIMPROF test at the 0.05 level (SIMPROF; $\mathrm{p}<0.05$ ) (ZHANG et al., 2012; YUANYUAN et al., 2014). Similarity percentage analyses (SIMPER, CLARKE \& WARWICK, 1994) were used to identify the percentage contribution of each taxon to the Bray-Curtis dissimilarity between the averages of groups observed in the nMDS plot. ANOSIM randomization (CLARKE \& WARWICK, 1994) was used to test for significant differences in species composition of diatoms growing on various substrates over the sampling period and for clusters that were significantly different in the cluster analysis. Canonical analysis of principal coordinates (CAP) was used to summarize the structure of diatom assemblages over the substrates and to determine which diatom taxa were considered important and directly responsible for the variations observed in the groups.

The relationship between the most abundant species and the main physico-chemical parameters was analysed by correlation matrices using Statistica 7.0. A total of 10 taxa with frequency

Table 1. Weekly values of the physical-chemical parameters in the Mrtvo More in 2016. T - temperature $\left({ }^{\circ} \mathrm{C}\right) ; \mathrm{S}$ - salinity (psu); O2/O2' - oxygen saturation; Chl a - chlorophyll-a concentrations $(\mu \mathrm{g} / \mathrm{L})$; SiO44- silicate $(\mu M)$; PO43- - phosphate $(\mu M)$; NO3- nitrate $(\mu M)$; NO2- - nitrite $(\mu M)$; NH4+ - ammonium $(\mu M) ;$ TIN - total inorganic nitrogen [(TIN) = $(\mathrm{NO} 3-)+(\mathrm{NO2}-)+(\mathrm{NH} 4+)](\mu \mathrm{M}) ; \mathrm{TRIX}=[\log 10(\mathrm{Chl}$ $a \times D \% O \times D I N \times T P)+k] / m$, the range of the TRIX scale from 0 to 10 (0-4 oligotrophic, 4-5 mesotrophic, 5-6 eutrophic, 6-10 extremely eutrophic).

\begin{tabular}{|c|c|c|c|c|}
\hline Season & \multicolumn{3}{|c|}{ Summer } & Autumn \\
\hline Date & 11-Aug & 17-Aug & 24-Aug & 2-Sep \\
\hline $\mathbf{T}$ & 26,60 & 23,70 & 21,70 & 24,00 \\
\hline $\mathbf{S}$ & 36,67 & 34,07 & 37,07 & 36,77 \\
\hline $\mathrm{NO}_{3}^{-}$ & 3,74 & 8,34 & 2,69 & 3,93 \\
\hline $\mathrm{NO}_{2}^{-}$ & 1,22 & 0,70 & 0,65 & 1,00 \\
\hline $\mathbf{N H}_{4}^{+}$ & 0,95 & 0,69 & 1,10 & 3,14 \\
\hline TIN & 5,91 & 9,73 & 4,44 & 8,06 \\
\hline $\mathrm{PO}_{4}{ }^{3-}$ & 0,48 & 0,18 & 0,29 & 0,48 \\
\hline $\mathrm{SiO}_{4}^{4-}$ & 6,93 & 11,35 & 7,22 & 9,43 \\
\hline Chl $a$ & 3,50 & 0,66 & 3,39 & 3,17 \\
\hline $\mathrm{O}_{2} / \mathbf{O}_{2}$ & 0,86 & 0,84 & 0,73 & 0,87 \\
\hline TRIX & 5,54 & 4,91 & 5,58 & 5,65 \\
\hline
\end{tabular}


of occurrence $\geq 30 \%$ and relative abundance $\geq$ $5.9 \%$ from 12 samples collected in Mrtvo More in August and September 2016 were selected for correlation analysis. Spearman-Rank correlations were performed after the KolmogorovSmirnov test was used for testing normality of the data distribution. Environmental data were first transformed $[\log (x+1)]($ CASSIE, 1962) to enable the correlation tests between variables. Only significant $(\mathrm{p}<0.05)$ values are reported.

\section{RESULTS}

\section{Environmental conditions}

In the investigated period, the water temperature in Lake Mrtvo More varied between $21.7{ }^{\circ} \mathrm{C}$ and $26.6{ }^{\circ} \mathrm{C}$, with an average of 24 ${ }^{\circ} \mathrm{C}$ (Table 1). The average salinity was 36.149 psu. Average nutrient concentrations were: 4.67 $\mu \mathrm{M} \mathrm{NO}_{3}{ }^{-}, 0.89 \mu \mathrm{M} \mathrm{NO}_{2}^{-}, 1.47 \mu \mathrm{M} \mathrm{NH}_{4}^{+}, 0.36$ $\mathrm{PO}_{4}{ }^{3-}$, and $8.74 \mu \mathrm{M} \mathrm{SiO}_{4}{ }^{4-}$. The concentrations of total inorganic nitrogen (TIN) ranged from $4.44\left(24^{\text {th }}\right.$ August $)$ to $9.73\left(17^{\text {th }}\right.$ August $) \mu \mathrm{M}$ and mostly follows the distribution of $\mathrm{NO}_{3}^{-}$. While the minimum chlorophyll $a$ concentration at the Mrtvo More site in this study was recorded on the $17^{\text {th }}$ of August $(0.66 \mu \mathrm{g} / \mathrm{L})$, the maximum concentration of $3.50 \mu \mathrm{g} / \mathrm{L}$ was recorded on $11^{\text {th }}$ of August. Average chlorophyll $a$ concentration for the investigated period was $2.68 \mu \mathrm{g} / \mathrm{L}$. Oxygen saturation $\left(\mathrm{O}_{2} / \mathrm{O}_{2}{ }^{\prime}\right)$ ranged from 0.73 to 0.87 (average 0.83 ). The average value of trophic index TRIX was 5.42, indicating eutrophic state according to Vollenweider's scale (VOLLENWEIDER et al., 1998).

\section{Taxonomic composition of the benthic diatom community}

During this study, a total of 97 specific and infraspecific diatom taxa were identified in the Mrtvo More (Table S1). A total of 42 genera were found. Genera with the greatest number of taxa were: Nitzschia (14 taxa), Mastogloia (8), Achnanthes (7), Cocconeis (6), Halamphora (5), Navicula (5), Amphora (4), Licmophora (4), Diploneis (3), and Grammatophora (3). In total, 4 genera (Ardissonea, Caloneis, Haslea,
Tabularia) were represented with two taxa each, while 28 were composed of one taxon only.

Altogether, 23 taxa were found in at least $50 \%$ or more of the total number of samples and could be characterised as taxa with a higher frequency of occurrence. Cocconeis scutellum var. scutellum Ehrenberg and Halamphora coffeiformis (C.Agardh) Levkov were the most frequent taxa, being present in all samples. Other taxa with high frequencies (75-92\%) were: Cocconeis costata W.Gregory (92\%), Cocconeis pseudomarginata W.Gregory (92\%), Nitzschia valdestriata Aleem \& Hustedt (83\%), Grammatophora oceanica Ehrenberg (75\%), and Licmophora paradoxa (Lyngbye) Agardh (75\%). In total, 37 taxa were found only once (sporadic taxa) during the investigated period (Table S1).

Regarding the substrate type, 47 diatom taxa have been characterized as exclusive; 26 were found only on glass, 16 were only on rock, while only 5 have been characterized as exclusively Padina sp. diatoms. Altogether, 27 taxa were found on all three investigated substrates.

Regarding the habitat type (sensu GUIRY \& GUIRY, 2020), the greatest number of diatom taxa (64) have been characterized as exclusively marine (Table S1). Among truly marine diatoms, two Cocconeis taxa (Cocconeis costata W.Gregory and C. pseudomarginata W.Gregory) showed a high frequency of appearance and were found in more than $92 \%$ of the total number of samples. Three exclusively freshwater species were observed in the diatom composition (Aulacoseira granulata (Ehrenberg) Simonsen, Amphora gracilis Ehrenberg, Placoneis flabellata (F.Meister) Kimura, H.Fukushima \& Ts.Kobayashi) with an average abundance of less than $1.5 \%$, whereas 10 species were characterized with marine-brackish habitat preference. Amongst these taxa, Achnanthes brevipes C.Agardh, C. scutellum var. scutellum, $H$. coffeiformis, Navicula salinicola Hustedt, and Synedra fulgens (Greville) W.Smith were present with a frequency over $58 \%$. Species with a broad habitat preference (marine to freshwater) observed in the study were Entomoneis paludosa (W.Smith) Reimer, H. coffeiformis, N. salinicola, and Nitzschia sigma (Kützing) W.Smith. 

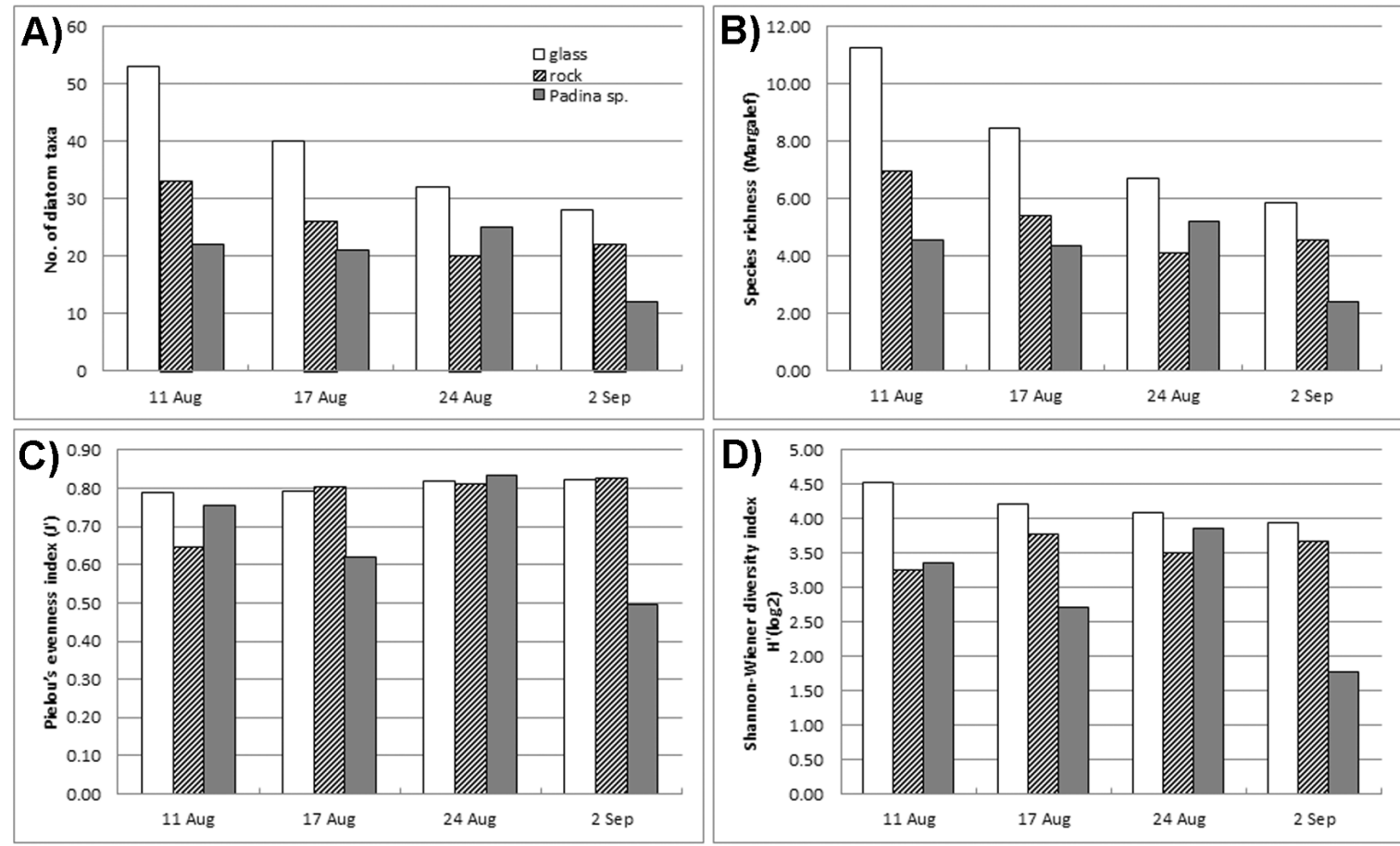

Fig. 2. Number of diatom taxa (A), Margalef's diversity index (B), Pielou's evenness index (C) and the Shannon-Wiener diatom diversity index (D) on glass, rock and Padina sp. during the period from 11 August to 2 September 2016 in Mrtvo More.

Table 2. Results of the ANOSIM test performed on species relative abundance data.

\begin{tabular}{|l|l|l|l|l|l|}
\hline & $\begin{array}{l}\text { Type of substrate } \\
\text { (artificial/natural) }\end{array}$ & $\begin{array}{l}\text { Type of benthic diatoms } \\
\text { (epilithic/epiphytic) }= \\
\text { Simprof Groups } \\
\mathbf{1} \& \text { 2 }\end{array}$ & $\begin{array}{l}\text { Substrate } \\
\text { (glass, rock, } \\
\text { Padina } \text { sp.) }\end{array}$ & $\begin{array}{l}\text { Substrate } \\
\text { (glass, rock) }\end{array}$ & $\begin{array}{l}\text { Substrate } \\
\text { (glass, Padina } \\
\text { sp.) }\end{array}$ \\
\hline $\boldsymbol{p}$ & $>0.05$ & 0.001 & 0.001 & $>0.05$ & 0.001 \\
\hline Global R & 0.042 & 0.693 & 0.676 & 0.375 & 0.958 \\
\hline
\end{tabular}

In general, the number of taxa per sample ranged from 12 ( $2^{\text {nd }}$ September, Padina sp.) to 53 (11 ${ }^{\text {th }}$ August, glass), with an average of 28 (Fig. 2A). An average number of diatom taxa for glass, rock, and Padina sp., were 38, 25, and 20, respectively. Margalef species richness index was calculated as $8.09,5.27$, and 4.13 for glass, rock and Padina sp. respectively (Fig. 2B). For glass samples, a decrease in species richness index from the middle of August was noted and the minimum occurred in September. Pielou's species evenness ranged from 0.50 to 0.83 (the average 0.75 ) with the minimum occurring in September on Padina sp. (Fig. 2C). The species diversity index (H', log2 based) varied from 1.78 to 4.52 , with an average of 3.56 (Fig. 2D). The minimum value was recorded in September on Padina sp. The average abundance of diatom taxa on the glass artificial substrate over the study period was $275856 \mathrm{cells} / \mathrm{cm}^{2}$ (data not shown) with a peak value of 333076 cells $/ \mathrm{cm}^{2}$ observed on $11^{\text {th }}$ of August.

According to nMDS, diatom assemblages differed significantly (ANOSIM, p < 0.05) between the epilithic diatom samples collected from natural rock samples and artificial glass substrates (group 1) and samples of epiphytic diatoms from Padina sp. (group 2) (Fig. 4). Additionally, four samples from the artificial glass substrates did not differ significantly from each other (Fig. 2, Tables S1, 2). While the diatom composition of artificial glass substrate did not differ significantly from that of rock substrate $(p>0.05)$, it differed significantly from that of macroalgae (Table 2). 

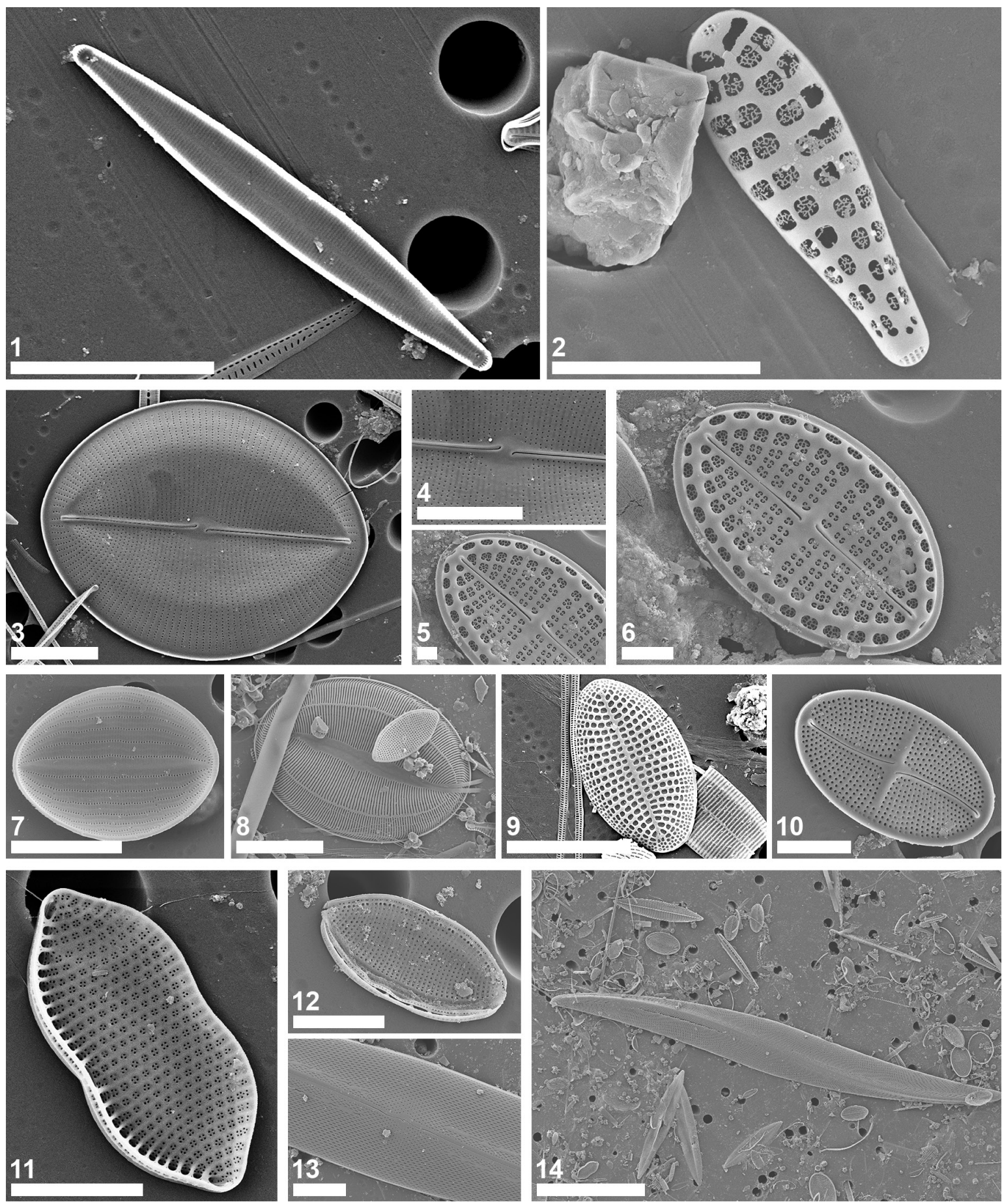

Fig. 3. Scanning electron microscope (SEM) micrographs of benthic diatoms in the Mrtvo More: Scanning electron microscope (SEM) micrographs of benthic diatoms in the Mrtvo More; 1) Tabularia fasciculata (C.Agardh) D.M.Williams \& Round; 2) Gedaniella mutabilis (Grunow) Chunlian Li \& Witkowski; 3, 4, 8) Cocconeis pseudomarginata W.Gregory; 5, 6) Cocconeis stauroneiformis H.Okuno; 7) Cocconeis convexa M.H.Giffen; 9) Cocconeis scutellum var. scutellum Ehrenberg; 10) Cocconeis dirupta var. flexella (Janisch \& Rabenhorst) Grunow; 11) Tryblionella coarctata (Grunow) D.G.Mann; 12) Psammodictyon rudum (Cholnoky) D.G.Mann; 13, 14) Pleurosigma formosum W. Smith. Scale bar: (5): $1 \mu \mathrm{m}$, (6) $2 \mu \mathrm{m},(2,10,11,12) 5 \mu \mathrm{m},(1,3,4,7,8,9,13) 10 \mu \mathrm{m},(14) 50 \mu \mathrm{m}$ 
Table 3. Correlation between 10 environmental variables and 10 diatom taxa [only significant $(\mathrm{p}<0.05)$ values are reported]. A dataset of 10 diatom taxa (with frequency of appearance $\geq 33 \%$ and average relative abundance $\geq$ 5.9\%) was selected. Abbreviations: $\mathrm{Si}-\mathrm{SiO}_{4}{ }^{4-}$, silicate, $\mathrm{TIN}-$ total inorganic nitrogen, $\mathrm{NO}_{3}{ }^{-}-$nitrate, $\mathrm{NO}_{2}{ }^{-}-$ nitrite, $\mathrm{NH}_{4}{ }^{+}-$ammonium, $\mathrm{PO}_{4}{ }^{3-}-$ phosphate, SAT - oxygen saturation $\left(\mathrm{O}_{2} / \mathrm{O}_{2}{ }^{\prime}\right), \mathrm{S}-$ salinity, $\mathrm{CHL}-$ chlorophyll $a$ concentrations, $\mathrm{T}$ - temperature. Codes for diatom taxa are: $\mathrm{Acbr}=$ Achnanthes brevipes $\mathrm{C}$.Agardh; Acps = Achnanthes pseudogroenlandica Hendey; Coco = Cocconeis costata W.Gregory; Cofl = Cocconeis dirupta var. flexella (Janisch \& Rabenhorst) Grunow; Codi = Cocconeis dirupta W.Gregory; Cosc = Cocconeis scutellum var. scutellum Ehrenberg; Haco $=$ Halamphora coffeiformis $($ C.Agardh) Levkov; Hahy = Halamphora hyalina (Kützing) Rimet \& R.Jahn; Nasa = Navicula salinicola Hustedt; Rhad = Rhabdonema adriaticum Kützing.

\begin{tabular}{|c|c|c|c|c|c|c|c|c|c|c|}
\hline & $T$ & S & $\mathrm{NO}_{3}^{-}$ & $\mathrm{NO}_{2}^{-}$ & $\mathrm{NH}_{4}{ }^{+}$ & TIN & $\mathrm{PO}_{4}{ }^{3-}$ & Si & CHL & SAT \\
\hline \multicolumn{11}{|l|}{$\mathbf{T}$} \\
\hline $\mathbf{S}$ & & & -0.97 & & & & & & 0.99 & \\
\hline $\mathrm{NO}_{3}^{-}$ & & -0.97 & & & & & & & -0.95 & \\
\hline \multicolumn{11}{|l|}{$\mathrm{NO}_{2}^{-}$} \\
\hline \multicolumn{11}{|l|}{$\mathrm{NH}_{4}{ }^{+}$} \\
\hline \multicolumn{11}{|l|}{ TIN } \\
\hline \multicolumn{11}{|l|}{$\mathrm{PO}_{4}{ }^{3-}$} \\
\hline \multicolumn{11}{|l|}{ Si } \\
\hline CHL & & 0.99 & -0.95 & & & & & & & \\
\hline \multicolumn{11}{|l|}{ SAT } \\
\hline \multicolumn{11}{|l|}{ Acbr } \\
\hline Acps & & & & & 0.99 & & & & & \\
\hline \multicolumn{11}{|l|}{ Coco } \\
\hline Cofl & & & & 0.99 & & & & & & \\
\hline \multicolumn{11}{|l|}{ Codi } \\
\hline \multicolumn{11}{|l|}{ Cosc } \\
\hline \multicolumn{11}{|l|}{ Haco } \\
\hline \multicolumn{11}{|l|}{ Hahy } \\
\hline Nasa & & & & & & & -0.97 & & & \\
\hline Rhad & & & & & & & & & -0.96 & \\
\hline
\end{tabular}

SIMPER analysis showed that Cocconeis dirupta W.Gregory, Cocconeis dirupta var. flexella (Janisch \& Rabenhorst) Grunow, Navicula salinicola Hustedt, Cocconeis costata W.Gregory, Halamphora coffeiformis (C.Agardh) Levkov, Achnanthes pseudogroenlandica Hendey, and Achnanthes brevipes C.Agardh contributed the most (cumulatively $60 \%$ ) to the variance between assemblages from groups 1 and 2. According to SIMPER analysis, C. dirupta, C. costata, C. scutellum var. scutellum, $H$. coffeiformis, C. pseudomarginata, and Gedaniella mutabilis (Grunow) Chunlian Li \&
Witkowski contributed the most (cumulatively 90\%) to the similarity between diatom assemblages from the four Padina sp. samples of group 2.

According to SIMPER analysis, C. dirupta, C. dirupta var. flexella, Halamphora hyalina (Kützing) Rimet \& R.Jahn, N. salinicola, H. coffeiformis, A. pseudogroenlandica, A. brevipes, and $C$. costata contributed the most (cumulatively $55 \%$ ) to the variance between assemblages from artificial and natural (rock + Padina sp.) substrates. While average dissimilarity between these substrates was $66 \%$, the average dissimi- 


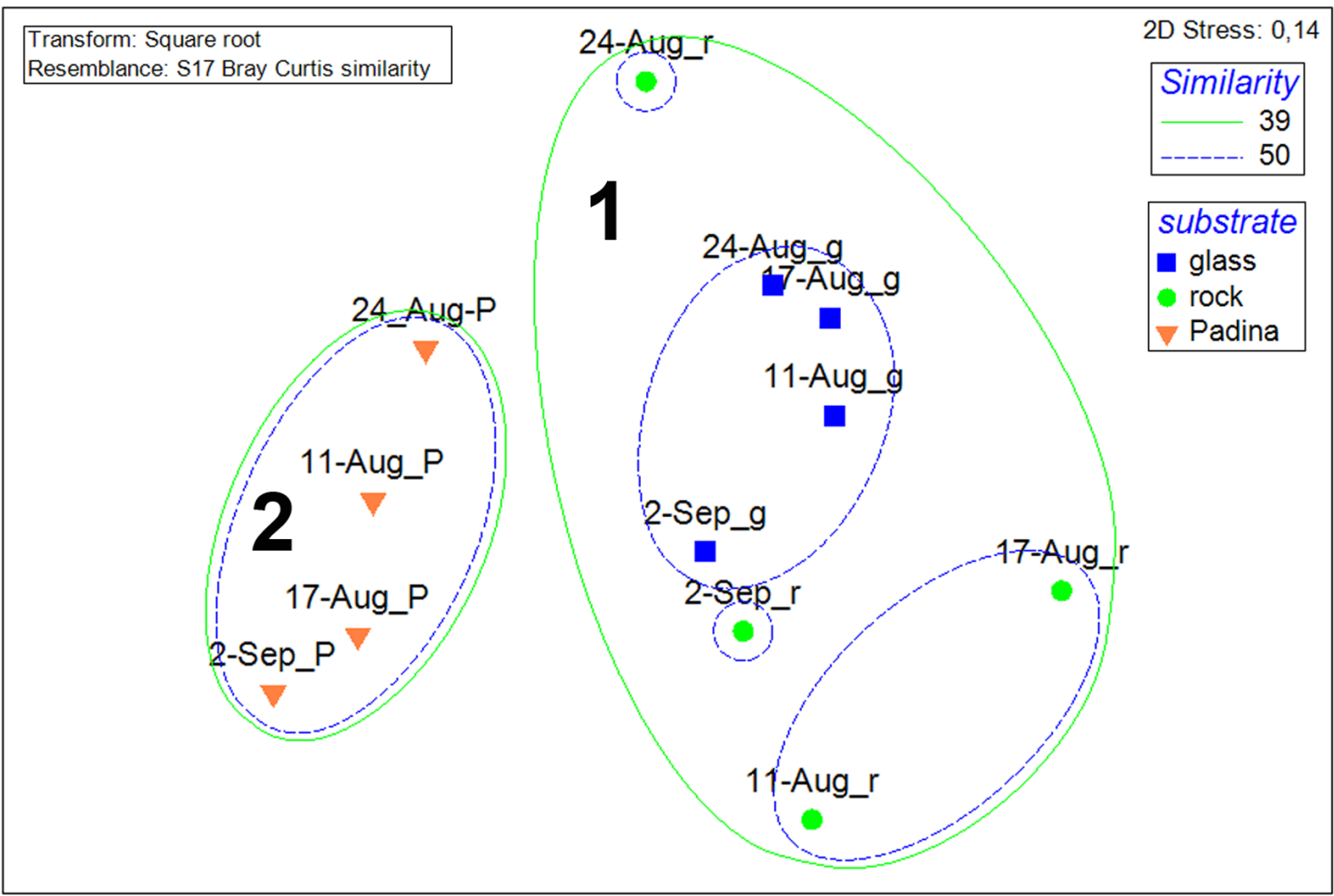

Fig. 4. Non-metric multidimensional scaling (nMDS) ordination on Bray-Curtis similarities matrices from square root transformed species-relative abundance data of periphytic diatom communities in 12 samples [4 of artificial substrate (glass slides); 4 of rock samples and 4 of Padina sp.] collected at depth of $1 \mathrm{~m}$ in the marine lake Mrtvo More in August-September 2016. For the ordination analysis all recorded diatom taxa were used. Numbers 1 and 2 indicate main clusters. $N=12$.

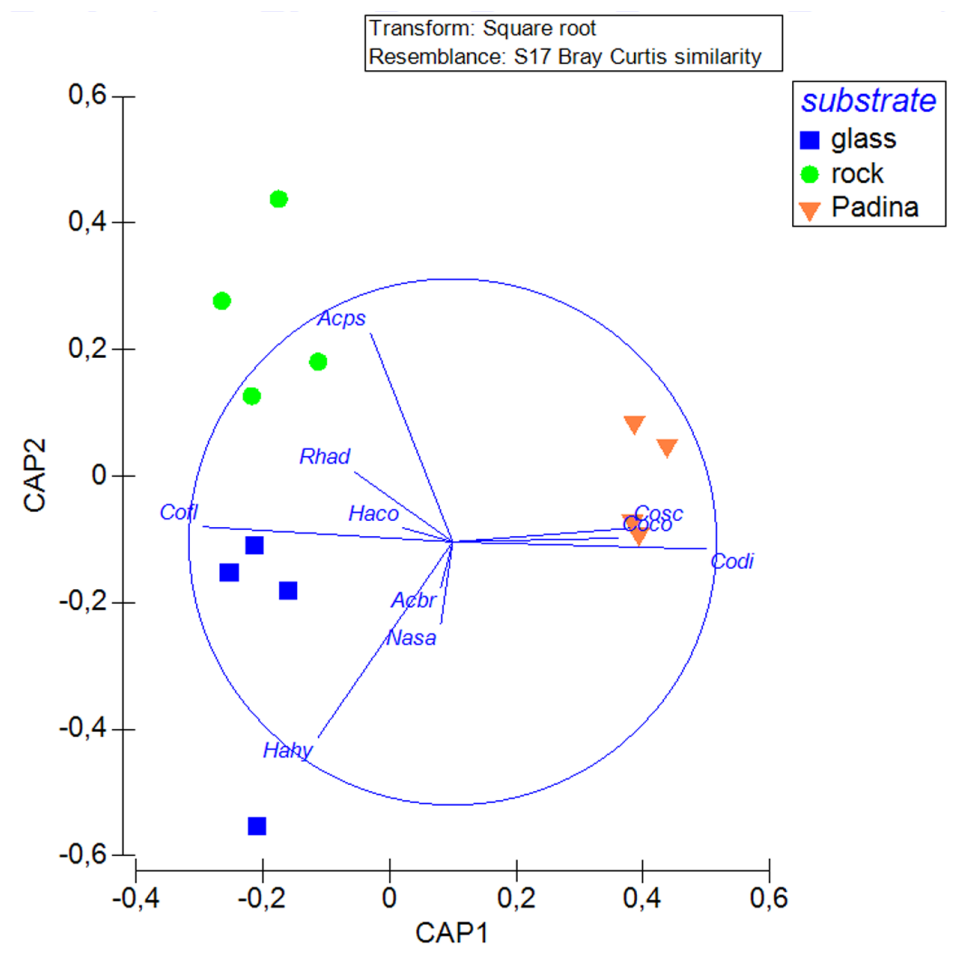

Fig. 5. Canonical analysis of Principle coordinates (CAP; Primer+PERMANOVA, U.K.). CAP biplot showing substrates and vectors of diatom relative abundance (\%) data (arrows) based on 12 samples. A dataset of 10 diatom taxa (with frequency of appearance $\geq 33 \%$ and average relative abundance $\geq 5.9 \%$ ) was selected. Codes for diatom taxa are: Acbr = Achnanthes brevipes C.Agardh; Acps = Achnanthes pseudogroenlandica Hendey; Coco = Cocconeis costata W.Gregory; Cofl = Cocconeis dirupta var. flexella (Janisch \& Rabenhorst) Grunow; Codi = Cocconeis dirupta W.Gregory; Cosc = Cocconeis scutellum var. scutellum Ehrenberg; Haco = Halamphora coffeiformis (C.Agardh) Levkov; Hahy = Halamphora hyalina (Kützing) Rimet \& R.Jahn; Nasa $=$ Navicula salinicola Hustedt; Rhad = Rhabdonema adriaticum Kützing. 
larity between groups 1 and 2 (i.e. epilithic and epiphytic diatom assemblages) was $74 \%$.

Canonical analysis of principle coordinates (CAP) showed that the samples collected from Padina sp. are more related with abundance of adnate diatoms, particularly C. dirupta, C. costata, C. scutellum var. scutellum (Fig. 5).

Significant $(\mathrm{p}<0.05)$ and positive correlation was observed between diatom relative abundance and $\mathrm{NO}_{2}$ - for $C$. dirupta var. flexella and between diatom relative abundance and $\mathrm{NH}_{4}{ }^{+}$for A. pseudogroenlandica. A significant negative correlation between diatom relative abundance and $\mathrm{PO}_{4}{ }^{3-}$ were identified for $N$. salinicola and between diatom relative abundance and Chl $a$ for Rhabdonema adriaticum Kützing (Table 3).

\section{DISCUSSION}

This study compares the diatom communities colonising glass slides in a marine lake to the naturally occurring communities in the epilithon and epiphyton. For the first time the ultrastructural analysis of benthic diatoms from Lake Mrtvo More was performed using scanning electron microscopy (SEM).

The average number of diatom taxa was higher on artificial substrates (38) than on natural substrates (23). Differences in the number of diatoms colonizing the different substrates emphasize the care needed in selecting a substratum on which to study the settlement of organisms, especially if the experiments are to be used for subsequent prediction (EDYVEAN et al., 1985). Although the number of diatom taxa recorded varied substantially between the different habitat types, for the one-month study period, both glass micro slides and natural rock substrates showed similar diatom community compositions, which indicates that diatom communities developing on artificial substrates accurately represent communities developing on natural substrates. The results of this study show that glass micro slides are suitable artificial substrates for providing representative samples of the natural epilithic diatom community composition in the studied lake.

Our results are in accordance with NENADOVIĆ et al. (2015) showing high colonization of glass artificial substrates by benthic diatoms. Previous studies have shown that newly introduced inorganic artificial substrates (e.g. glass) in a marine environment provide an opportunity to monitor the initial development and succession of diatoms in the periphyton (NENADOVIĆ et al., 2015; CAR et al., 2020). In contrast, DEDIĆ et al. (2015) investigated artificial and natural substrates in a karstic spring and reported that artificial substrates include fewer diatom taxa. However, this might be related to the differences between marine and freshwater ecosystems, whereas generally marine environments provide a greater diatom biodiversity compared to freshwater ecosystems.

Significant differences were found between the diatom assemblages colonizing Padina sp. and glass artificial substrates, showing that microscopic slides cannot be used as a representative alternative tool for epiphytic diatom analysis in further diatom studies. These differences in the structure of diatom assemblages could be the result of the interactions of several significant drivers. Comparative studies have shown that colonization of artificial substrates differs from that of natural substrates and that living substrates (e.g. macrophytes) act as additional sources of nutrients for attached communities (HAMILTON \& DUTHIE, 1984; SABATER et al., 1998). However, while artificial glass substrates could show some resemblance in terms of diatom communities, possibly similar surfaces (epilithon) yield diatoms so as to create a biofilm in which common taxa could grow as suggested by our findings. In addition, the observed differences that occurred are probably due to the structural complexity of macrophytes. Several studies have reported that the diatom composition of macrophytes could differ from epilithon and species such as Cocconeis spp. show abundance in the community which could attach to the macrophyte (CAR et al., 2012; MAJEWSKA et al., 2014). Our results confirmed that species of Cocconeis costata, $C$. dirupta, $C$. pseudomarginata and C. scutellum var. scutellum were present on Padina sp., accompanied by Gedaniella mutabilis and the frequent taxa Halamphora coffeiformis adapted to all three substrates. In general, adnate taxa (e.g. $C$. 
Table S1. Species and infraspecific taxa of benthic diatoms in the Mrtvo More in August-September 2016, including data on their familyet al. 2020, Guiry \& Guiry, 2020), weekly distribution in samples of different substrates (G - glass, $R$ - rock, P-Padina sp.), absol

\begin{tabular}{|c|c|c|c|c|}
\hline Taxon & Genus & Family & & Gl \\
\hline & & & $\mathrm{S}$ & M \\
\hline Achnanthes brevipes C.Agardh & Achnanthes & Achnanthaceae & + & + \\
\hline Achnanthes brevipes var. intermedia (Kützing) Cleve & Achnanthes & Achnanthaceae & . & + \\
\hline Achnanthes groenlandica (Cleve) Grunow & Achnanthes & Achnanthaceae & . & + \\
\hline Achnanthes hyperboreoides A.Witkowski, Metzeltin \& Lange-Bertalot & Achnanthes & Achnanthaceae & . & + \\
\hline Achnanthes kuwaitensis Hendey & Achnanthes & Achnanthaceae & . & + \\
\hline Achnanthes pseudogroenlandica Hendey & Achnanthes & Achnanthaceae & . & + \\
\hline Achnanthes separata Hustedt & Achnanthes & Achnanthaceae & . & + \\
\hline Amphora bigibba var. interrupta (Grunow) Cleve & Amphora & Catenulaceae & . & + \\
\hline Amphora gracilis Ehrenberg & Amphora & Catenulaceae & . & . \\
\hline Amphora laevissima W.Gregory & Amphora & Catenulaceae & . & + \\
\hline Amphora sp. 1 & Amphora & Catenulaceae & . & . \\
\hline Ardissonea crystallina (C.Agardh) Grunow & Ardissonea & Ardissoneaceae & . & . \\
\hline Ardissonea formosa (Hantzsch) Grunow & Ardissonea & Ardissoneaceae & . & + \\
\hline Aulacoseira granulata (Ehrenberg) Simonsen & Aulacoseira & Aulacoseiraceae & $\cdot$ & . \\
\hline Bacillaria socialis (Gregory) Ralfs & Bacillaria & Bacillariaceae & . & + \\
\hline Caloneis bicuneata (Grunow) Boyer & Caloneis & Naviculaceae & . & + \\
\hline Caloneis liber var. linearis Cleve & Caloneis & Naviculaceae & . & + \\
\hline Climacosphenia moniligera Ehrenberg & Climacosphenia & Climacospheniaceae & . & + \\
\hline Cocconeis convexa M.H.Giffen & Cocconeis & Achnanthidiaceae & . & + \\
\hline Cocconeis costata W.Gregory & Cocconeis & Achnanthidiaceae & . & + \\
\hline Cocconeis dirupta var. flexella (Janisch \& Rabenhorst) Grunow & Cocconeis & Achnanthidiaceae & . & + \\
\hline Cocconeis dirupta W.Gregory & Cocconeis & Achnanthidiaceae & . & + \\
\hline Cocconeis pseudomarginata W.Gregory & Cocconeis & Achnanthidiaceae & . & + \\
\hline Cocconeis scutellum var. scutellum Ehrenberg & Cocconeis & Achnanthidiaceae & + & + \\
\hline Coronia decora (Brébisson) Ruck \& Guiry & Coronia & Surirellaceae & . & + \\
\hline Craspedostauros decipiens (Hustedt) E.J.Cox & Craspedostauros & Mastogloiaceae & . & + \\
\hline Diploneis crabro (Ehrenberg) Ehrenberg & Diploneis & Diploneidaceae & . & + \\
\hline Diploneis nitescens (W.Gregory) Cleve & Diploneis & Diploneidaceae & . & + \\
\hline Diploneis splendida Cleve & Diploneis & Diploneidaceae & . & + \\
\hline Entomoneis paludosa (W.Smith) Reimer & Entomoneis & Entomoneidaceae & . & + \\
\hline Fallacia ny (Cleve) D.G.Mann & Fallacia & Sellaphoraceae & . & + \\
\hline Fragilaria sp.1 & Fragilaria & Fragilariaceae & . & . \\
\hline Gedaniella mutabilis (Grunow) Chunlian Li \& Witkowski & Gedaniella & Staurosiraceae & . & + \\
\hline Grammatophora angulosa var. islandica (Ehrenberg) Grunow & Grammatophora & Grammatophoraceae & . & + \\
\hline Grammatophora marina (Lyngbye) Kützing & Grammatophora & Grammatophoraceae & . & + \\
\hline Grammatophora oceanica Ehrenberg & Grammatophora & Grammatophoraceae & + & + \\
\hline Halamphora coffeiformis (C.Agardh) Levkov & Halamphora & Amphipleuraceae & $\cdot$ & + \\
\hline Halamphora hyalina (Kützing) Rimet \& R.Jahn & Halamphora & Amphipleuraceae & + & + \\
\hline
\end{tabular}


evel affiliations, general environment (GE: S-soil taxa, $M$ - marine, B-brackish, F-freshwater, (sensu Witkowski et al. 2000, Kociolek ite (n), percentage (\%) frequency of appearance and average relative abundance (Avg. $R A \%)$.

\begin{tabular}{|c|c|c|c|c|c|c|c|c|c|c|c|c|c|c|c|c|}
\hline \multirow[b]{3}{*}{ B } & \multirow[b]{3}{*}{$\mathrm{F}$} & \multicolumn{12}{|c|}{ Date } & \multirow{3}{*}{$\mathrm{n}$} & \multirow{3}{*}{$\begin{array}{l}\text { Freq. } \\
(\%)\end{array}$} & \multirow{3}{*}{$\begin{array}{l}\text { Avg. } \\
\text { RA } \\
(\%)\end{array}$} \\
\hline & & \multicolumn{3}{|c|}{11 August } & \multicolumn{3}{|c|}{17 August } & \multicolumn{3}{|c|}{24 August } & \multicolumn{3}{|c|}{2 September } & & & \\
\hline & & G & $\mathrm{R}$ & $P$ & G & $\mathrm{R}$ & $P$ & G & $\mathrm{R}$ & $\mathrm{P}$ & G & $\mathrm{R}$ & $\mathrm{P}$ & & & \\
\hline+ & . & . & + & + & + & . & . & + & + & . & + & + & . & 7 & 58,33 & 6,07 \\
\hline+ & + & + & . & . & . & . & . & . & . & . & . & . & . & 1 & 8,33 & 1,00 \\
\hline . & . & . & . & . & . & . & . & . & . & . & . & + & . & 1 & 8,33 & 2,50 \\
\hline . & . & + & . & . & . & . & . & . & . & . & . & . & . & 1 & 8,33 & 0,75 \\
\hline . & . & + & . & . & + & + & . & + & . & + & . & + & . & 6 & 50,00 & 3,11 \\
\hline . & . & + & + & + & . & + & + & . & + & . & . & + & + & 8 & 66,67 & 6,34 \\
\hline . & . & . & + & . & . & . & . & . & . & . & . & + & . & 2 & 16,67 & 0,38 \\
\hline . & . & + & . & . & + & + & . & . & . & + & + & . & . & 5 & 41,67 & 0,95 \\
\hline . & + & + & + & + &. & . & + & . & . & + & + & + & + & 8 & 66,67 & 1,44 \\
\hline$\cdot$ & . & + & . & . & . & . & . & . & . & . & . & . & . & 1 & 8,33 & 0,75 \\
\hline . & . & + & + & . & . & . & . & . &. & . & + & . & . & 3 & 25,00 & 1,67 \\
\hline+ & . & . & + & . & . & . & . & . & . & . &. & . & . & 1 & 8,33 & 0,25 \\
\hline . & . & + & + & . & . & . & & . & . &. &. & . & . & 2 & 16,67 & 0,25 \\
\hline. & + & . & + & . & . & . & . & . & . & . &. & . & . & 1 & 8,33 & 0,25 \\
\hline+ & . & + & . & . & . & . & + & + & . & . & + & . & . & 4 & 33,33 & 0,62 \\
\hline . & . & . & . & . & . & + & . & . & . &. &. & . & . & 1 & 8,33 & 1,00 \\
\hline . & . & + & . & . & . & . & . & . & . & . & . & . & . & 1 & 8,33 & 0,25 \\
\hline . & . & . & . & . & + & . & & + &. & . & . & . & . & 2 & 16,67 & 0,25 \\
\hline . & . & . & . & . & . & . & . & + & . & + & . & + & . & 3 & 25,00 & 1,582 \\
\hline . & . & + & + & + & + & . & + & + & + & + & + & + & + & 11 & 91,67 & 8,15 \\
\hline . & . & + & + & . & + & + & . & + & + & . & + & + & . & 8 & 66,67 & 17,61 \\
\hline . & . & . & . & + & . & . & + & . & . & + & . &. & + & 4 & 33,33 & 40,88 \\
\hline$\cdot$ & . & + & + & + & + & + & + & + &. & + & + & + & + & 11 & 91,67 & 2,61 \\
\hline+ & . & + & + & + & + & + & + & + & + & + & + & + & + & 12 & 100,00 & 5,94 \\
\hline . & . & . & . & . & + & . & . & + &. &. & . & . & . & 2 & 16,67 & 0,25 \\
\hline . & . & . & . & . & . & . & . & . & + & + &. & . & . & 2 & 16,67 & 4,13 \\
\hline . & . & . & + & . & . & + & . & . & . &. &. & . & . & 2 & 16,67 & 0,50 \\
\hline . & . & . & + & . & . & + & . & . & . & . & . & . & . & 2 & 16,67 & 1,13 \\
\hline . & . & . & . & . & . & . & + & . &. &. & . & . & . & 1 & 8,33 & 0,25 \\
\hline+ & + & + & . & . & . & . & . & . & . & . & . & . & . & 1 & 8,33 & 0,75 \\
\hline . & . & . & . & + & . & . & . & . & . &. & . & . & . & 1 & 8,33 & 1,00 \\
\hline . & . & . & . & . & + & . & . & . & . & . & . & . & . & 1 & 8,33 & 1,00 \\
\hline . & . & + & . & + & + & . & + & + & + & + & + & + & + & 10 & 8,33 & 1,25 \\
\hline . & . & . & + & . & . & . & . & . & . & . & . & . & . & 1 & 8,33 & 0,25 \\
\hline$\cdot$ & . & . & + & + & + & + & . & . & . & . & + & . & . & 5 & 41,67 & 0,55 \\
\hline+ & . & + & + & + & + & + & + & . & . & + & + & . & + & 9 & 75,00 & 1,17 \\
\hline+ & + & + & + & + & + & + & + & + & + & + & + & + & + & 12 & 100,00 & 8,04 \\
\hline 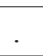 & . & + & . & . & + & + & + & + & . & . & + & $\cdot$ & . & 6 & 50,00 & 6,77 \\
\hline
\end{tabular}




\begin{tabular}{|c|c|c|c|c|}
\hline Halamphora kolbei (Aleem) Álvarez-Blanco \& S.Blanco & Halamphora & Amphipleuraceae & . & + \\
\hline Halamphora pseudohyalina (Simonsen) J.G.Stepanek \& Kociolek & Halamphora & Amphipleuraceae & . & + \\
\hline Halamphora subangularis (Hustedt) Levkov & Halamphora & Amphipleuraceae & . & + \\
\hline Haslea spicula (Hickie) Bukhtiyarova & Haslea & Naviculaceae & . & + \\
\hline Haslea duerrenbergiana (Hustedt) F.A.S.Sterrenburg, nom. inval. & Haslea & Naviculaceae & + & + \\
\hline Hyalosynedra laevigata (Grunow) D.M.Williams \& Round & Hyalosynedra & Ulnariaceae & . & + \\
\hline Licmophora flabellata (Greville) C.Agardh & Licmophora & Licmophoraceae & . & . \\
\hline Licmophora paradoxa (Lyngbye) Agardh & Licmophora & Licmophoraceae & . & + \\
\hline Licmophora pfannkuckae Giffen & Licmophora & Licmophoraceae & . & . \\
\hline Licmophora tincta (C.Agardh) Grunow & Licmophora & Licmophoraceae & . & + \\
\hline Mastogloia binotata (Grunow) Cleve & Mastogloia & Mastogloiaceae & . & + \\
\hline Mastogloia cuneata (Meister) R.Simonsen & Mastogloia & Mastogloiaceae & . & + \\
\hline Mastogloia erythraea Grunow & Mastogloia & Mastogloiaceae & . & + \\
\hline Mastogloia exilis Hustedt & Mastogloia & Mastogloiaceae & . & + \\
\hline Mastogloia fimbriata (T.Brightwell) Grunow & Mastogloia & Mastogloiaceae & . & + \\
\hline Mastogloia ignorata Hustedt & Mastogloia & Mastogloiaceae & . & + \\
\hline Mastogloia ovalis A.Schmidt & Mastogloia & Mastogloiaceae & . & + \\
\hline Mastogloia pseudolatecostata T.A.Yohn \& R.A.Gibson & Mastogloia & Mastogloiaceae & . & + \\
\hline $\begin{array}{l}\text { Nanofrustulum sopotense (Witkowski \& Lange-Bertalot) E.Morales, } \\
\text { C.E.Wetzel \& Ector }\end{array}$ & Nanofrustulum & Staurosiraceae & . & + \\
\hline Navicula directa (W.Smith) Ralfs & Navicula & Naviculaceae & . & + \\
\hline Navicula flagellifera Hustedt & Navicula & Naviculaceae & + & + \\
\hline Navicula salinicola Hustedt & Navicula & Naviculaceae & . & + \\
\hline Navicula sp. & Navicula & Naviculaceae &. & . \\
\hline Navicula sp.1 & Navicula & Naviculaceae & . & . \\
\hline Nitzschia agnita Hustedt & Nitzschia & Bacillariaceae & . & + \\
\hline Nitzschia compressa (Bailey) Boyer var. compressa & Nitzschia & Bacillariaceae & . & + \\
\hline Nitzschia compressa var. elongata (Grunow) Lange-Bertalot & Nitzschia & Bacillariaceae &. & + \\
\hline Nitzschia distans W.Gregory & Nitzschia & Bacillariaceae & . & + \\
\hline Nitzschia fusiformis Grunow & Nitzschia & Bacillariaceae & . & + \\
\hline Nitzschia grossestriata Hustedt & Nitzschia & Bacillariaceae & . & + \\
\hline Nitzschia insignis W.Gregory & Nitzschia & Bacillariaceae & . & + \\
\hline Nitzschia laevis Frenguelli & Nitzschia & Bacillariaceae & . & + \\
\hline Nitzschia macilenta W.Gregory & Nitzschia & Bacillariaceae & . & + \\
\hline Nitzschia marginulata var. didyma Grunow & Nitzschia & Bacillariaceae & + & + \\
\hline Nitzschia reversa W.Smith & Nitzschia & Bacillariaceae & . & + \\
\hline Nitzschia sigma (Kützing) W.Smith & Nitzschia & Bacillariaceae & + & + \\
\hline Nitzschia subconstricta Desikachary \& Prema & Nitzschia & Bacillariaceae & . & + \\
\hline Nitzschia valdestriata Aleem \& Hustedt & Nitzschia & Bacillariaceae & . & . \\
\hline Opephora sp. & Opephora & Staurosiraceae & . & . \\
\hline Parlibellus delognei (Van Heurck) E.J. Cox & Parlibellus & Berkeleyaceae & . & + \\
\hline Placoneis flabellata (F.Meister) Kimura, H.Fukushima \& Ts.Kobayashi & Placoneis & Gomphonemataceae & . & . \\
\hline Pleurosigma formosum W. Smith & Pleurosigma & Pleurosigmataceae &. & + \\
\hline Pleurosigma sp. 1 & Pleurosigma & Pleurosigmataceae &. &. \\
\hline Psammodictyon rudum (Cholnoky) D.G.Mann & Psammodictyon & Bacillariaceae & . & + \\
\hline
\end{tabular}




\begin{tabular}{|c|c|c|c|c|c|c|c|c|c|c|c|c|c|c|c|c|}
\hline . & . & + & & & + & & . & . & + & + &. & . & . & 4 & 33,33 & 0,69 \\
\hline . & . & . & . & + &. & . & + & . & . & + &. &. & + & 4 & 33,33 & 2,25 \\
\hline . & . & . & . & . & + & . & . & . & . & + & . & . & . & 2 & 16,67 & 0,88 \\
\hline+ & . & + & . &. &. & . & . & . & . & . & . & . & . & 1 & 8,33 & 0,25 \\
\hline+ & . & . & + & + & + & . & + & + & . & + &. &. &. & 6 & 50,00 & 1,957 \\
\hline. &. &. &. &. &. &. & &. & . & . & + &. &. & 1 & 8,33 & 0,50 \\
\hline+ &. & + &. &. &. &. &. & + & . & . & + & + &. & 4 & 33,33 & 1,56 \\
\hline. & . & + & + & + & + & + &. & + & + & . & + & + &. & 9 & 75,00 & 1,91 \\
\hline+ & . & + & & & & &. &. & . & . &. &. &. & 1 & 8,33 & 0,25 \\
\hline . & . & . & & . & . & . & . & . & + & . &. &. &. & 1 & 8,33 & 0,25 \\
\hline . & . & + & . & . & + & . & . & . & . & . & . & . & . & 2 & 16,67 & 0,38 \\
\hline. & . & + & . & . & + & + &. & + &. &. &. &. &. & 4 & 33,33 & 0,75 \\
\hline . & . & + & & & & & . & . & . &. & . & . & . & 1 & 8,33 & 0,50 \\
\hline. &. &. & . & . & . & + &. &. &. &. &. &. &. & 1 & 8,33 & 0,50 \\
\hline . & . & + & + & . & + & . & . & . & . & . & . &. &. & 3 & 25,00 & 0,42 \\
\hline. & . & + & & & + & . &. &. &. &. &. &. &. & 2 & 16,67 & 0,25 \\
\hline. & . & . & & & & &. & + &. &. &. &. &. & 1 & 8,33 & 0,50 \\
\hline. & . & + & . & . &. & . & + &. &. &. &. &. &. & 2 & 16,67 & 0,25 \\
\hline+ & . & . & 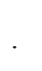 & . & + & . & . & $\cdot$ & $\cdot$ & & . & . & . & 1 & 8,33 & 2,75 \\
\hline . & . & + & . & + & + & . & & + & + &. & + & + &. & 7 & 58,33 & 1,03 \\
\hline. &. & + &. & + & + &. & + & + &. &. & + &. &. & 6 & 50,00 & 2,25 \\
\hline+ & + & + & 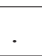 & + & + & + & + & + & + & + & . & . & . & 8 & 66,67 & 8,55 \\
\hline . &. & . & . & . &. & $\cdot$ &. &. & . &. &. & + &. & 1 & 8,33 & 2,50 \\
\hline. & . & . &. &. &. &. & . & + &. &. &. &. &. & 1 & 8,33 & 7,67 \\
\hline+ & + & . & . & . & . & . & . & . & + &. & . & . &. & 1 & 8,33 & 2,50 \\
\hline. & . & + & + & & . & + & + & + &. &. &. &. &. & 5 & 41,67 & 0,55 \\
\hline. & . & . & + & . & . & . &. &. &. &. &. &. &. & 1 & 8,33 & 0,50 \\
\hline . & . & + & . &. &. &. & . &. &. &. &. &. &. & 1 & 8,33 & 1,00 \\
\hline. &. & + &. &. &. &. &. &. & + &. &. &. &. & 2 & 16,67 & 1,63 \\
\hline. & . & + & . &. & + & . &. & + &. &. &. &. &. & 3 & 25,00 & 0,83 \\
\hline. & . & . & . &. & + & $\cdot$ & + &. &. &. &. &. &. & 2 & 16,67 & 0,25 \\
\hline . & . & + & . & + & + &. & . & + & + & + & + &. &. & 7 & 58,33 & 2,46 \\
\hline . &. & . &. & . &. &. &. & + &. & . &. &. &. & 1 & 8,33 & 0,25 \\
\hline . & . & . & . & . & + & . & 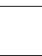 & . & . & . & . & . & . & 1 & 8,33 & 0,50 \\
\hline+ & + & + & . & & . & . &. &. & . & . &. &. &. & 1 & 8,33 & 0,50 \\
\hline+ & + & . & + & . & . & . & 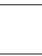 &. & + & + &. &. &. & 3 & 25,00 & 1,58 \\
\hline. &. &. & + &. &. &. &. &. & . & . &. &. &. & 1 & 8,33 & 0,50 \\
\hline+ & . & + & . & $\cdot$ & . & . &. &. & + & . &. &. &. & 2 & 83,33 & 4,04 \\
\hline . & . & + & & & & & . & . & . & + & . &. &. & 2 & 16,67 & 3,13 \\
\hline . &. & . & & + & + & + &. & + & . & . &. &. &. & 4 & 33,33 & 0,93 \\
\hline . & + & . & . & . & . & $\cdot$ & . & . & . & + &. & . & . & 1 & 8,33 & 1,50 \\
\hline . &. & + & . & . & + & . &. &. & . & . & + &. &. & 3 & 25,00 & 0,42 \\
\hline$\cdot$ & $\cdot$ & & & + & & & & . & . & . &. &. & . & 1 & 8,33 & 0,25 \\
\hline . & . & + & + & + & + & & 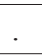 & + & + & + & + &. &. & 8 & 66,67 & 2,03 \\
\hline
\end{tabular}




\begin{tabular}{|l|l|l|l|l|}
\hline Rhabdonema adriaticum Kützing & Rhabdonema & Rhabdonemataceae & + \\
\hline Rhoicosphenia marina (Kützing) M.Schmidt & Rhoicosphenia & Rhoicospheniaceae & $\cdot$ \\
\hline Rhopalodia pacifica Krammer & Rhopalodia & Rhopalodiacae & $\cdot$ \\
\hline Seminavis sp. & Seminavis & Naviculaceae \\
\hline Staurosira sp. & Staurosira & Staurosiraceae & $\cdot$ \\
\hline Striatella unipunctata (Lyngbye) C.Agardh & Striatella & Striatellaceae & $\cdot$ \\
\hline Surirella fastuosa (Ehrenberg) Ehrenberg & Surirella & Surirellaceae & $\cdot$ \\
\hline Synedra fulgens (Greville) W.Smith & Synedra & Fragilariaceae \\
\hline Tabularia fasciculata (C.Agardh) D.M.Williams \& Round & Tabularia & Ulnariaceae & + \\
\hline Tabularia investiens (W.Smith) D.M.Williams \& Round & Tabularia & Ulnariaceae & + \\
\hline Toxarium undulatum J.W.Bailey & Toxarium & Toxariaceae \\
\hline Trachyneis aspera (Ehrenberg) Cleve & Trachyneis & Naviculaceae & + \\
\hline Triceratium finnmarchicum Grunow & Triceratium & Triceratiaceae \\
\hline Trigonium sp. 1 & Trigonium & Trigoniaceae & $\cdot$ \\
\hline Tryblionella coarctata (Grunow) D.G.Mann & Tryblionella & Bacillariaceae & + \\
\hline
\end{tabular}

Fig. S1. Mean values of precipitation $(L)$ in Dubrovnik for the period from 1961 to 2017 (provided by the Croatian Meteorological and Hydrological Service) together with precipitation (L) in Dubrovnik during 2016

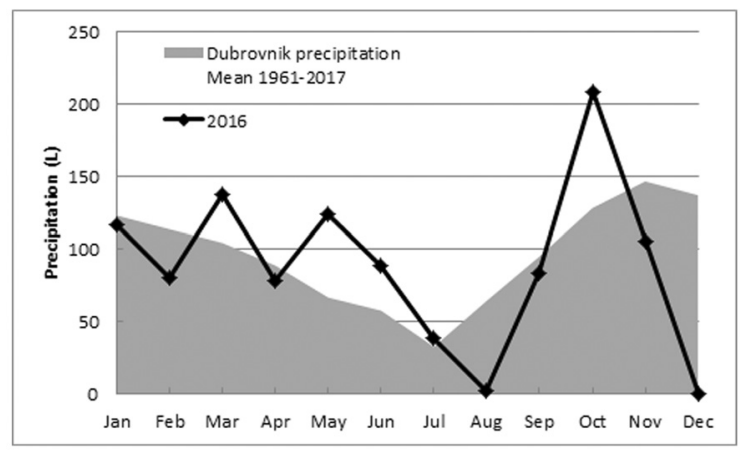

scutellum var. scutellum and C. dirupta) adhere strongly horizontally to the substrate by means of their raphe valve and may easily benefit from nutrient exchange with the substrate due to their mode of adhesion over the valve face (ROUND, 1981; SULLIVAN, 1984; ROMAGNOLI et al., 2014).

Diatom composition of the lake, in terms of genera, was dominated by mainly marine diatoms with a few freshwater and brackish taxa observed, as would be expected due to the connection between the lake and the open sea. The genus Mastogloia, one of the largest marine diatom genera (PENNESI et al., 2011, and references therein), comprised of species which can be found within different biotopes (ÇOLAK SABAN-
CI, 2013) was one of the richest in taxa number in our study. The most frequent Mastogloia species in our study was Mastogloia cuneata (Meister) R.Simonsen. Interestingly, Mastogloia cyclops Voigt, which has been characterized as a good indicator of coastal zones (WACHNICKA et al., 2010) was not recorded during this one-month investigation.

The most frequent taxa in this study $(C$. scutellum var. scutellum and $H$. coffeiformis) were also found on different substrates and do not seem to have a preference either for a geographic region or for the substrate type (ROMAGNOLI et al., 2014). Although in our study C. scutellum was recorded on all substrates, it is generally considered as a typical epiphytic taxon (ULANOVA \& SNOEIJS, 2006). That is in accordance with results of this study as $C$. scutellum was recorded with the highest abundances on Padina sp.

Although precipitation in August 2016 was very low, (2.6 L, Fig. S1, data from Dubrovnik meteorological station for 1961-2017, Croatian Meteorological and Hydrological Service) the presence of taxa associated with brackish to freshwater habitats probably correlates with the precipitation regime as there is no other source of freshwater, such as a river or underground spring, that would feed the lake. The observed monthly diatom communi- 


\begin{tabular}{|c|c|c|c|c|c|c|c|c|c|c|c|c|c|c|c|c|}
\hline . & . & + & + & . & + & + & . & . & . & + & + & + & . & 7 & 58,33 & 5,89 \\
\hline$\cdot$ & . & $\cdot$ & + & . & + & + & $\cdot$ & . & . & . & . & . & . & 3 & 25,00 & 4,33 \\
\hline . & . & . & . & . & + & . &. & . & . & . & . & . & . & 1 & 8,33 & 0,25 \\
\hline$\cdot$ & . & + & . & . & . & . & . & + & . & . & + & + & . & 4 & 33,33 & 1,43 \\
\hline$\cdot$ & . & . & . & . & + & . & . & . & . & . & . & . & . & 1 & 8,33 & 1,75 \\
\hline$\cdot$ & . & $\cdot$ & . & . & . & . &. & . & . & . & + & + & + & 3 & 25,00 & 2,67 \\
\hline. & . & + & + & . & . & + & . & . & . & . & . & . & . & 3 & 25,00 & 0,58 \\
\hline+ & . & + & + & . & . & + & + & + & . & . & + & + & . & 7 & 58,33 & 1,07 \\
\hline+ & . & + & . & . & . & . & & . & . & . & . & . & . & 1 & 8,33 & 0,25 \\
\hline . & . & + & . & . & . & . &. & + & . & . & + & . & . & 3 & 25,00 & 0,67 \\
\hline$\cdot$ & . & + & + & . & + & . &. & . & . & . & $\cdot$ & . & . & 3 & 25,00 & 0,42 \\
\hline$\cdot$ & . & + & + & . & . & + & + & $\cdot$ & $\cdot$ & + & . & + & + & 7 & 58,33 & 2,29 \\
\hline+ & . & $\cdot$ & + & $\cdot$ & . & $\cdot$ & $\cdot$ & $\cdot$ & $\cdot$ & . & . & . & . & 1 & 8,33 & 0,50 \\
\hline$\cdot$ & . & . & . & $\cdot$ & $\cdot$ & + &. & . &. & $\cdot$ & . & . & . & 1 & 8,33 & 0,75 \\
\hline . & . & + & . & . & + & + & . & + & + & + & + & . & . & 7 & 58,33 & 3,24 \\
\hline
\end{tabular}

ties with the presence of brackish and freshwater species reveal that diatom composition can be affected by precipitation. A range of factors can naturally be expected to affect diatom development in the lake, especially when influenced by tourist activities, and this possibility will be investigated in-depth in the future.

Although similar diatom assemblages developed on glass artificial substrates and on rocks, there was no correlation observed between communities according to different sampling dates. This is most likely due to the short period of the study. The four months in the field might not be enough for the artificial substrate to reach a stable community similar to the natural rocks. Thus, if the immersion time had been longer, the assemblages may have been even more significantly similar to natural rock assemblages. Consistent quantitative and qualitative data are still needed to better determine the seasonal changes of the epilithic assemblages in the lake.

The results of the study of bacterial and diatom community in the same lake show a close relationship between diatoms and changes of physico-chemical parameters, especially nutrient concentrations (CAR et al., 2020). Although CAR et al. (2020) investigated the initial colonization of bacteria and diatoms on an immersed artificial substrate in the marine Lake Mrtvo
More, the observed variations in diatom composition and distribution demands further investigations if they are to be considered as potential indicator species of change.

The results of the present study focusing on a comparison between glass artificial substrate and two native habitat builder substrates (macroalgae and rocks) show that the initial hypotheses are supported and the observed diatom composition is shown to be influenced by the substrate. It can be concluded that glass artificial substrates are not suitable as an alternative for epiphytic but can be for epilithic diatom assemblage monitoring. Rocks (natural substrates) collected for comparison showed similar diatom community compositions to the artificial substrate analysed. Hence, diatom communities developing on artificial substrates accurately represent the diatom community of one particular natural substratum and can potentially be used as a representative alternative tool for studies of epilithic diatom analysis in further diatom studies. However, studies over long periods would show whether diatom assemblages associated with the artificial substrate are sensitive to local variation in environmental conditions and whether glass artificial substrates might be a valid standard replicable tool for monitoring purposes. In addition, the characterization of the 
biofilm for other locations and durations should be tested and the diatom assemblages on other natural substrates, such as different macroalgae, should be compared with those captured by the artificial substrate. However, the use of artificial habitat collectors as a method for epilithic diatom monitoring should be considered. This study is only the first step to find a standard methodology for benthic monitoring studies that can be used regardless of the geographic location.

\section{ACKNOWLEDGEMENTS}

The authors thank Steve Latham (UK) for improving the English, Dr. Nesil ERTORUN for his SEM documentation perform, and two anonymous reviewers whose helpful comments

This research was supported by Croatian Science Foundation (HRZZ, IP-2014-09-2945 \& IP-2019-04-9043).

\section{REFERENCES}

APHA. 2005. Standard Methods for the Examination of Water and Wastewater. $21^{\text {st }}$ edition, American Public Health Association. Washington, DC., USA, 1368 pp.

BARBIERO, R.P. 2000. A multi-lake comparison of epilithic diatom communities on natural and artificial substrates. Hydrobiologia, 438: 157-170. DOI: 10.1023/A:1004182231973.

BARTOLE, L., C. WELKER, G., DELLAVALLE \& G. BRESSAN. 1991-1994. Primi stadi di colonizzazione "a diatomee" di un substrato duro artificiale in due stazioni fisse del Golfo di Trieste (nord Adriatico). Nova Thalassia., 12: 163-189.

BÉRARD-THERRIAULT, L., A. CARDINAL \& M. POULIN. 1986. Les diatomées (Bacillariophyceae) benthiques de substrats durs des eaux marines et saumâtres du Québec. 6. Naviculales: Cymbellaceae et Gomphonemaceae. Naturaliste Canadien (Revue d'Ecologie et de Systématique), 113: 405-429.

BÉRARD-THERRIAULT, L., A. CARDINAL \& M. POULIN. 1987. Les diatomées (Bacillariophyceae) benthiques de substrats durs des eaux marines et saumâtres du Québec. 8. Centrales. Naturaliste Canadien (Revue d'Ecologie et de Systématique), 114: 81-113.

BATISTIĆ, M., R. GARIĆ \& J.C. MOLINERO. 2014. Interannual variations in Adriatic Sea zooplankton mirror shifts in circulation regimes in the Ionian Sea. Clim. Res., 61: 231-240. DOI: $10.3354 / \mathrm{cr} 01248$.

BURIĆ, Z., K. CAPUT \& D. VILIČIĆ. 2004. Distribution of the diatom Cocconeis scutellum in the karstic estuary (Zrmanja, eastern Adriatic Sea). Biologia, Bratislava, 59(1): 1-7.

CAPUT MIHALIĆ, K., D. VILIČIĆ, M. AHEL, Z. BURIĆ \& M. CARIĆ. 2008. Periphytic algae development in the upper reach of the Zrmanja estuary (eastern Adriatic coast). Vie et Milieu, 58: 3-4, 203-213.

CAR, A., A. WITKOWSKI, S. DOBOSZ, D.D. BURFEIND, A. MEINESZ, N. JASPRICA, M. RUPPEL, K.J. KURZYDLOWSKI \& T. PLOCIŃSKI. 2012. Description of a new marine diatom, Cocconeis caulerpacola sp. nov. (Bacillariophyceae), epiphytic on invasive Caulerpa species. Eur. J. Phycol., 47(4): 433-448. DOI: 10.1080/09670262.2012.735255.

CAR, A., A. WITKOWSKI, N. JASPRICA, S. LJUBIMIR, M. ČALIĆ, S. DOBOSCZ, I. DUPČIĆ RADIĆ \& E. HRUSTIĆ. 2019a. Epilithic diatom communities from areas of invasive Caulerpa species (Caulerpa taxifolia and Caulerpa cylindracea) in the Adriatic Sea, NE Mediterranean. Mediterr. Mar. Sci., 20/1: 151-173. DOI: 10.12681/mms. 14330.

CAR, A., A. WITKOWSKI, S. DOBOSCZ, N. JASPRICA \& S. LJUBIMIR. 2019b. Epiphytic diatom assemblages on invasive algae Caulerpa taxifolia and autochtonous Halimeda tuna and Padina sp. from the Adriatic Sea-summer/autumn aspect. Oceanol. Hydrobiol. Stud., 48(3): 209-226. DOI: 10.1515/ohs-2019-0000.

CAR, A., D. HAFNER, S. LJUBIMIR, I. DUPČIĆ RADIĆ, S. BOBANOVIĆ-ĆOLIĆ \& N. JASPRICA. 2020. Colonization of bacteria and diatoms on an artificial substrate in a marine lake (eastern 
Adriatic Sea, NE Mediterranean). Acta Bot. Croat., 79(2): 212-227. DOI: 10.37427/botcro-2020-028.

CARREIRA-FLORES, D., R. NETO, H. FERREIRA, E. CABECINHA, G. DIAZ-AGRAS \& P.T. GOMES. 2020. Artificial substrates as sampling devices for marine epibenthic fauna: A quest for standardization. Reg. Stud. Mar. Sci., 37: 1-11. DOI: 10.1016/j.rsma.2020.101331.

CIBIC, T. \& O. BLASUTTO. 2011. Living marine benthic diatoms as indicators of nutrient enrichment: a case study in the Gulf of Trieste. In: J.C. Compton (Editor). Diatoms: Ecology and Life Cycle. Hauppauge, New York: Nova Science Publishers, pp. 169-184.

CLARKE, K.R. \& R.N. GORLEY. 2006. PRIMER v6: User Manual/Tutorial. PRIMER-E, Plymouth.

CLARKE, K.R. \& R.M. WARWICK. 1994. Change in marine communities: an approach to statistical analysis and interpretation. Natural Environmental Research Council, Plymouth Marine Laboratory, Plymouth, 144 pp.

ÇOLAK SABANCI, F. 2013. Species of Mastogloia (Bacillariophyceae) - new for the Aegean coast of Turkey. Ovo je Mediterr. Mar. Sci., 14: 129-140. DOI: 10.12681/mms.331.

CRNČEVIĆ, M., A. BRATOŠ \& P. TUTMAN. 2017. Preliminary data on fish fauna in small marine lake on Lokrum Island-special reserve and Natura 2000 site, Croatia. In: N. Pojskić and B. Kalamujić-Stroil (Editors), Book of Abstracts of $1^{\text {st }}$ South-east European Ichthyological Conference INGEB, Sarajevo: p. 20.

DEDIĆ, A., A. PLENKOVIĆ-MORAJ, K. KRALJBOROJEVIĆ \& D. HAFNER. 2015. The first report on periphytic diatoms on artificial and natural substrate in the karstic spring Bunica, Bosnia and Herzegovina. Acta Bot Croat., 74 (2): 393-406. DOI: 10.1515/botcro-2015-0029.

EDYVEAN, R.G.J., G.A. RANDS \& B.L. MOSS. 1985. A Comparison of Diatom Colonization on Natural and Artificial Substrata in Seawater. Estuar Coast Shelf Sci., 20: 233-238. DOI: 10.1016/0272-7714(85)90040-X.

FACCA, C., A. SFRISO \& G. SOCAL. 2002. Temporal and spatial distribution of diatoms in the surface sediments of the Venice Lagoon. Bot. Mar. 45: 170-183. DOI: 10.1515/ BOT.2002.016.

FACCA, C. \& A. SFRISO. 2007. Epipelic diatom spatial and temporal distribution and relationship with the main environmental parameters in coastal waters. Estuar. Coast. Shelf Sci., 75: 35-49. DOI: 10.1016/j.ecss.2007.03.033.

FALKOWSKI, P.G., O. SCHOFIELD, M.E. KATZ, B. VAN DE SCHOOTBRUGGE \& A.H. KNOLL. 2004. Why is the land green and the ocean red? In: H.R. Thierstein and J.R. Young (Editors), Coccolithophores. From molecular processes to global impacy. Berlin: Springer, pp. 429-453.

FRANZO, A., T. CIBIC, P. DEL NEGRO \& C. DE VITTOR. 2015. Spatial distribution of microphytobenthos, meiofauna and macrofauna in the north-western Adriatic Sea: a synoptic study. Advances in Oceanography and Limnology 6: 58-75. DOI: 10.4081/aiol.2015.5470.

GARIĆ, R. \& M. BATISTIĆ. 2016. Description of Brooksia lacromae sp. nov. (Tunicata, Thaliacea) from the Adriatic Sea. Eur. J. Taxon., 196: 1-13. DOI: 10.5852/ejt.2016.196.

GIOVANARDI, F. \& R.A. VOLLENWEIDER. 2004. Trophic conditions of marine coastal waters: experience in applying the Trophic Index TRIX to two areas of the Adriatic and Tyrrhenian seas. Journal of Limnology, 63: 199-218.

GUIRY, M.D. \& G.M. GUIRY. 2020. AlgaeBase. World-wide electronic publication, National University of Ireland, Galway. Retrieved October, 20, 2020 from http://www.algaebase.org.

HAFNER, D., A. CAR, N. JASPRICA, T. KAPETANOVIĆ \& I. DUPČIĆ RADIĆ. 2018a. Relationship between marine epilithic diatoms and environmental variables in oligotrophic bay, NE Mediterranean. Mediterr Mar Sci., 19 (2): 223-239. DOI: $10.12681 / \mathrm{mms} .14151$.

HAFNER, D., N. JASPRICA \& A. CAR. 2018b. Taxonomic survey of benthic diatoms in Neum Bay, south-eastern Adriatic. Nat. Croat., 27(1): 1-26. DOI: 10.20302/NC.2018.27.1.

HAMILTON, P.B. \& H.C. DUTHIE. 1984. Periphyton colonization of rock surfaces in a boreal 
forest stream studied by scanning electron microscopy and track autoradiography, J. Phycol., 20: 525-532. DOI: 10.1111/j.00223646.1984.00525.x.

HARTLEY, B., R. ROSS \& D. WILLIAMS. 1986. A Check-List of the Freshwater, Brackish and Marine Diatoms of the British Isles and Adjoining Coastal Waters. J. Mar. Biol. Assoc. U.K., 66(3), 531-610. DOI: 10.1017/ S0025315400042235.

HARTLEY, B., H.G. BARBER \& J.R. CARTER. 1996. An Atlas of British Diatoms. Bristol: Biopress, $601 \mathrm{pp}$.

HENDEY, N.I. 1964. An introductory account of the smaller algae of British coastal waters. Part V. Bacillariophyceae (Diatoms). Ministry of Agriculture, Fisheries and Food, Fisheries Investigations, Seies IV, London, $317 \mathrm{pp}$.

HOAGLAND, K.D., A. ZLOTSKY \& C.G. PETERSON. 1986. The source of algal colonizers on rock substrates in a freshwater impoundment. In: L.V. Evans and K.D. Hoagland (Editors), Algal Biofouling Elsevier, Amsterdam, pp. 21-39. DOI: 10.1016/ S0166-1116(08)72168-X.

HOLM-HANSEN, O., C.J. LORENZEN, R.W. HOLMES \& J.D.H. STRICKLAND. 1965. Fluorometric determination of chlorophyll. Journal $\mathrm{Du}$ Conseil, 301: 3-15. DOI: 10.1093/ices$\mathrm{jms} / 30.1 .3$.

IVANČIĆ, I. \& D. DEGOBBIS. 1984. An optimal manual procedure for ammonia analysis in natural waters by the indophenol blue method. Water Research, 18: 1143-1147. DOI: 10.1016/0043-1354(84)90230-6.

KANJER, L., M. MUCKO, A. CAR \& S. BOSAK. 2019. Epiphytic diatoms on Posidonia oceanica (1.) Delile leaves from eastern Adriatic Sea. Nat. Croat., 28(1): 1-20. DOI: 10.20302/ NC.2019.28.1.

KARYDIS, M. 2009. Eutrophication assessment of coastal waters based on indicators: a literature review. Global NEST Journal, 11(4): 373-390.

KOCIOLEK, J.P., K. BALASUBRAMANIAN, S. BLANCO, M. COSTE, L. ECTOR, Y. LIU, M. KULIKOVSKIY, N. LUNDHOLM, T. LUDWIG, M. POTAPOVA, F. RIMET, K. SABBE, S. SALA, E. SAR, J. TAYLOR,
B. VAN DE VIJVER, C.E. WETZEL, D.M., WILLIAMS, A. WITKOWSKI \& J. WITKOWSKI. 2020. DiatomBase. Retrieved October, 20, 2020 from http://www.diatombase.org

KWANDRANS, J. 2007. Diversity and ecology of benthic diatom communities in relation to acidity, acidification and recovery of lakes and rivers. Diatom Monographs (v.9). Koeltz Scientific Books, Königstein, 168 pp.

LAMBERTI, G.A. \& V.H. RESH. 1985. Distribution of benthic algae and macroinvertebrates along a thermal stream gradient. Hydrobiologia, 128: 13-21 DOI: 10.1007/BF00008935.

LANE, C.M., K.H. TAFFS \& J.L. CORFIELD. 2003. A comparison of diatom community structure on natural and artifi cial substrates. Hydrobiologia, 493: 65-79. DOI: 10.1023/A:1025498732371.

LEGENDRE, L. \& P. LEGENDRE. 1983. Numerical ecology. Developments in environmental modelling. 3. Elsevier, Amsterdam, 419 pp.

LEVKOV, Z., K. CAPUT MIHALIĆ \& L. ECTOR. 2010. A taxonomical study of Rhoicosphenia Grunow (Bacillariophyceae) with a key for identification of selected taxa. Fottea, 10: 145-200.

MAJEWSKA, R., D. D'ALELIO \& M. DE STEFANO. 2014. Cocconeis Ehrenberg (Bacillariophyta), a genus dominating diatom communities associated with Posidonia oceanica Delile (monocotyledons) in the Mediterranean Sea. Aquat. Bot., 112: 48-56.

MEJDANDŽIĆ, M., T. IVANKOVIĆ, M. PFANNKUCHEN, J. GODRIJAN, D. MARIĆ PFANNKUCHEN, J. HRENOVIĆ \& Z. LjUBEŠIĆ. 2015. Colonization of diatoms and bacteria on artificial substrates in the northeastern coastal Adriatic Sea. Acta Bot Croat., 74: 407-422. DOI: 10.1515/botcro-2015-0030.

MIHO, A. \& A. WITKOWSKI. 2005. Diatom (Bacillariophyta) flora of Albanian coastal wetlands taxonomy and ecology: A review. Proceedings of the California Academy of Sciences, 56: 129-145.

MUNDA, I.M. 2005. Seasonal fouling by diatoms on artificial substrata at different depths near Piran (Gulf of Trieste, Northern Adriatic). Acta Adriat., 46: 137-157. 
NENADOVIĆ, T., T. ŠARČEVIĆ, H. ČIŽMEK, J. GODRIJAN, D. MARIĆ PFANNKUCHEN, M. PFANNKUCHEN \& Z. LJUBEŠIĆ. 2015. Development of periphytic diatoms on different artificial substrates in the Eastern Adriatic Sea. Acta Bot Croat., 74: 377-392. DOI: 10.1515/ botcro-2015-0026.

PENNESI, C., M. POULIN, M. DE STEFANO, T. ROMAGNOLI \& C. TOTTI. 2011. New insights to the ultrastructure of some marine Mastogloia species section Sulcatae (Bacillariophyceae), including Mastogloia neoborneensis sp. nov. Phycologia, 50: 548-562. DOI: 10.2216/1039.1.

PERAGALLO, H. \& M. PERAGALLO. 1897.-1908. Diatomées marines de France et des districts maritimes voisin. Micrographe-Editeur, Grez-sur-Loing (S.-et-M.), 491 pp.

PIELOU, E.C. 1966. The measurement of diversity in different types of biological collections. J. Theor. Biol., 13: 131-144. DOI: 10.1016/0022-5193(66)90013-0.

POULIN, M., L. BÉRARD-THERRIAULT \& A. CARDINAL. 1984. Les diatomées benthiques de substrats durs des eaux marines et saumâtres du Québec. 3. Fragilarioideae (Fragilariales, Fragilariaceae). Naturaliste Can. (Rev. Ecol. Syst.), 111: 349-367.

POULIN, M., L. BÉRARD-THERRIAULT, A. CARDINAL \& P.B. HAMILTON. 1990. Les diatomées (Bacillariophyta) benthiques de substrats durs des eaux marines et saumâtres du Québec. 9. Bacillariaceae. Naturaliste Can. (Rev. Ecol. Syst.), 117: 73-101.

PRIMPAS, I. \& M. KARYDIS. 2011. Scaling the trophic index (TRIX) in oligotrophic marine environments. Environ. Monit. Assess., 178, 257-269. DOI: 10.1007/s10661-010-1687-x.

RICARD, M. 1974. Etude taxonomique des diatomées marines du lagon de Vairao (Tahiti) 1. Le genre Mastogloia. Rev. Algol., nouvelle série. 11: 161-177.

RICARD, M. 1975. Quelques diatomées nouvelles de Tahiti décrites en microscopie photonique et électronique à balayage. Bull. Mus. Natl. Hist. Nat., 3e serie, 326, 201-229.

RICARD, M. 1977. Les peuplements de diatomeés des lagons de l'Archipel de la Société
(Polynésie Française). Rev. Algol., nouvelle série, 12: 137-336.

ROMAGNOLI, T., C. TOTTI, S. ACCORONI, M. DE STEFANO \& C. PENNESI. 2014. SEM analysis of the epibenthic diatoms on Eudendrium racemosum (Hydrozoa) from the Mediterranean Sea. Turk. J. Botany, 38: 566-594. DOI:10.3906/bot-1305-52.

ROUND, F.E. 1981. The ecology of algae. Cambridge University Press, Cambridge.

SABATER, S., S.V. GREGORY \& J.R. SEDELL. 1998. Community dynamics and metabolism of benthic algae colonizing wood and rock substrates in a forest stream. J. Phycol., 34: 561-567. DOI: 10.1046/j.15298817.1998.340561.x.

SDRIGOTTI, E., V. BARBARIOL \& C. WELKER. 1999. Diatom assemblages in coastal shallow waters at the water-sediment interface (Gulf of Trieste, north Adriatic Sea). Annals for Istrian and Mediterranean Studies, Series historia naturalis, 2: 191-202.

SNOEIJS, P. 1993. Intercalibration and distribution of diatoms in the Baltic Sea, 1. Baltic Marine Biologists Publication 16a, Uppsala: Opulus Press, pp. 1-129.

SNOEIJS, P. 1999. Marine and brackish waters. In: P. Snoeijs and M. Diekmann (Editors). Swedish Plant Geography. Acta Phytogeogr. Suec. 84. Uppsala: Opulus Press. pp. 187-212.

SNOEIJS, P. \& N. BALASHLOVA. 1998. Intercalibration and distribution of diatoms in the Baltic Sea, 5. Baltic Marine Biologists Publication 16e, Uppsala: Opulus Press, pp. 1-144.

SNOEIJS, P. \& J. KASPEROVICIENÉ. 1996. Intercalibration and distribution of diatoms in the Baltic Sea, 4. Baltic Marine Biologists Publication 16d, Uppsala: Opulus Press, pp. 1-125.

SNOEIJS, P. \& M. POTAPOVA. 1995. Intercalibration and distribution of diatoms in the Baltic Sea, 3. Baltic Marine Biologists Publication 16c, Uppsala: Opulus Press, pp. 1-125.

STEVENSON, R.J. \& Y. PAN. 1999. Assessing environmental conditions in rivers and streams with diatoms. In: E.F. Stoermer and J.P. Smol (Editors). The Diatoms. Application for the environmental and earth sciences. Cambridge: University Press, pp. 469. 
SULliVAN, M.J. 1984. Community structure of epiphytic diatoms from the Gulf Coast of Florida, U.S.A. In: D.G. Mann (Editor). Proceedings of the 7th Diatom Symposium, Koeltz, Koenigstein, 373-384.

TOLOMIO, C. \& C. ANDREOLI. 1989. Recherches sur le periphyton à diatomées dans un vivier de la Lagune de Venise (mai 1984mai 1985). Diatom Res., 4: 151-162. DOI: 10.1080/0269249X.1989.9705060.

TOLOMIO, C., I. MORO, E. MOSCHIN \& A. VALANDRO. 1999. Résultats préliminaires sur les diatomées benthiques de substrats meubles dans la lagune de Venise, Italie (Mars 1994-Janvier 1995). Diatom Res., 14: 367-379. DOI: 10.1080/0269249X.1999.9705478.

TOLOMIO, C., E. MOSCHIN \& B. DUZZIN. 2002. Distribution des diatomées benthiques de substrats meubles dans le bassin sud de la lagune de Venise, Italie. Diatom Res., 17: 401-414. DOI: 10.1080/0269249X.2002.9705557.

TOTTI, C. 2003. Influence of the plume of the river Po on the distribution of subtidal microphytobenthos in the northern Adriatic Sea. Bot. Mar., 46: 161-178. DOI: https://doi. org/10.1515/BOT.2003.017.

TOTTI, C., E. CUCCHIARI, M. DE STEFANO, C. PENNESI, T. ROMAGNOLI \& G. BAVESTRELLO. 2007. Seasonal variations of epilithic diatoms on different hard substrates, in the northern Adriatic Sea. J. Mar. Biol. Assoc. U.K., 87: 649658. DOI: $10.1017 / \mathrm{S} 0025315407054665$.

TUCHMAN, M.L. \& R.J. STEVENSON. 1980. Comparison of clay tile, sterilized rock, and natural substrate diatom communities in a small stream in Southeastern Michigan, USA. Hydrobiologia, 75: 73-79. DOI: 10.1007/ BF00006564.

ULANOVA, A. \& P. SNOEIJS. 2006. Gradient responses of epilithic diatom communities in the Baltic Sea proper. Estuar. Coast. Shelf Sci., 68: 661-674. DOI: 10.1016/j.ecss.2006.03.014.

UNESCO. 1973. International oceanographic tables, Volume 2. National Institute of
Oceanography of Great Britain and UNESCO, Paris, 141 pp.

VOLLENWEIDER, R.A., F. GIOVANARDI, G. MONTANARI \& A. RINALDI. 1998. Characterization of the trophic conditions of marine coastal waters with special reference to the NW Adriatic Sea: proposal for a Trophic Scale, Turbidity and generalized Water Quality Index. Environmetrics, 9(3): 329-357. DOI: 10.1002/(SICI)1099$095 \mathrm{X}(199805 / 06) 9: 3<329$ : : A ID ENV308>3.0.CO;2-9.

WACHNICKA, A., E. GAISER, L. COLLINS, T. FRANKOVICH \& J. BOYER. 2010. Distribution of diatoms and development of diatom-based models for inferring salinity and nutrient concentrations in Florida Bay and adjacent coastal wetlands of South Florida (USA). Estuaries Coast., 33: 1080-1098. DOI: 10.1007/ s12237-010-9283-4.

WEISS, R.F. 1970. The solubility of nitrogen, oxygen and argon in water and seawater. Deep Sea Research, 17: 721-735. DOI: 10.1016/0011-7471(70)90037-9.

WINTER, J.G. \& H.C. DUTHIE. 2000. Stream epilithic, epipelic and epiphytic diatoms: habitat fidelity and use in biomonitoring. Aquat. Ecol., 34: 345-353. DOI: 10.1023/A:1011461727835

WITKOWSKI, A., H. LANGE-BERTALOT \& D. METZELIN. 2000. Diatom flora of marine coasts I. In: H. Lange-Bertalot (Editor). Iconographia diatomologica, vol. 7, Ruggell, Liechtenstein: A.R.G. Gantner, 1-925 pp.

YUANYUAN, L., W. ZHANG \& X. HENGLONG. 2014. Colonization dynamics of periphytic diatoms in coastal waters of the Yellow Sea, northern China. Acta Oceanologica Sinica, 33: 160-165. DOI: 10.1007/s13131-014-0466-X. ZHANG, W., H. XU, Y. JIANG, M. ZHU \& K.A.S. AL-RASHEID. 2012. Colonization dynamics in trophic-functional structure of periphytic protist communities in coastal waters. Mar. Biol., 159: 735-748. DOI: 10.1007/s00227011-1850-0. 


\title{
Usporedba struktura zajednica bentoskih dijatomeja na prirodnim i umjetnim podlogama u morskom jezeru (Jadransko more)
}

\author{
Ana CAR, Dubravka HAFNER' Iris DUPČIĆ RADIĆ*, Aydin KALELI, \\ Stijepo LJUBIMIR i Cüneyt NADIR SOLAK
}

Kontakte-pošta: iris@unidu.hr

\begin{abstract}
SAŽETAK
Kako bi se razumjele razlike između naseljavanja na umjetnim i prirodnim podlogama, u ovom istraživanju uspoređivani su sastavi dijatomeja s tri alternativna staništa (epiliton, epifiton i umjetni supstrat). U tu svrhu uzorci su sakupljani tjedno između kolovoza i rujna 2016. na jednoj lokaciji u plitkom morskom jezeru Mrtvo More na otoku Lokrumu kod Dubrovnika (Južni Jadran, Hrvatska).

Osim detaljne analize svjetlosnim mikroskopom, po prvi put je provedena i ultrastrukturna analiza bentoskih dijatomeja iz jezera Mrtvo More pomoću elektronske mikroskopije (SEM). U 12 uzoraka identificirano je ukupno 97 vrsta dijatomeja. Vrste Cocconeis scutellum Ehrenberg i Halamphora coffeiformis (C.Agardh) Levkov bile su najčešće vrste u uzorcima. Vrijednosti Shannon-Wiener (H') indeksa varirale su od 1,78 (u rujnu na vrsti Padina sp.) do 4,52 (u kolovozu na staklu).

Prema nMDS ordinaciji, razlikuju se dvije skupine zajednica bentoskih dijatomeja: epiliton i umjetna staklena podloga kao Grupa 1 i makroalge kao Grupa 2. Rezultati analize pokazali su da zajednice bentoskih dijatomeja koje se razvijaju na umjetnim podlogama, odgovaraju dijatomejskoj zajednici kamene podloge i da se stoga mogu koristiti kao reprezentativni alternativni alat za proučavanje epilitskih dijatomeja u daljnjim eksperimentima.
\end{abstract}

Ključne riječi: Bacillariophyta; plitko morsko jezero; identifikacija vrsta; bioraznolikost;

Sjevero-istočno Sredozemlje 
